\title{
A FENNTARTHATÓ FEJLŐDÉS STRATÉGIAI ELEMEI A RURÁLIS TÉRSÉGEKBEN
}

\author{
(Elements of Sustainable Rural Development Strategy)
}

\section{SZÖRÉNYINÉ KUKORELLI IRÉN}

Kulcsszavak:

fenntarthatófejlödés rurális terek stratégia Magyarország EU

A fenntarthato fejlödés megvalósitása nem lehet csak egy ország, vagy egy régió feladata, hanem tekintet nélkill a Föld bármely pontjára, mindannyiunk felelössége. 2001 óta az Európai Uniónak is létezik a fenntartható fejlödésre vonatkozó stratégiája. Az EU stratégiájăhoz kapcsolódóan minden tagországnak rendelkeznie kell a fenntartható fejlödésre vonatkozó stratégiával, amit Magyarország 2005-ben készitett el, úgy, hogy az átfogô stratégia a különbözö szektorokra, és a teriulet és vidékfejlesztésre készült részstratégiákból építkezett. A tanulmány ebböl a fenntartható vidékfejlödés résztanulmányból táplálkozik, mikor azt kívánja bemutatni, hogy a magyarországi rurális térségek milyen stratégiai irányokon keresztül kapcsolódhatnak az EU stratégiájához, hogyan érhetik el a fenntartható fejlödés elemeit. De mielött a stratégiai irányokat és intézkedéseket vennénk sorba, elöször röviden bemutatjuk a vidéki térségek legfontosabb társadalmi és gazdasági trendjeit, hogy világos legyen, honnan kell elindulni a fenntartható fejlödés megualósítása felé.

\section{Bevezetés}

A fenntartható fejlődés fogalma, koncepciója a hetvenes évektöl datálható, de használata a nyolcvanas évektől vált egyre gyakoribbá, attól kezdve, amikor az ENSZ közgyủlése 1983-ban megalakította a Környezet és Fejlesztés Világbizottságot (World Commission on Environment and Development = WCED). A Világbizottság négyévi mủködésének eredményeképpen megszületett a „Közös Jövönk” (Our Common Future) dokumentum, melyet az ENSZ Közgyủlése 1987-ben elfogadott. Ezt nevezik a Világbizottság elnöke után Brundtland jelentésnek. A környezetvédelem mellett a gazdaság is előtérbe került, mégpedig úgy, hogy a fenntarthatóság a gazdasági és a környezeti érdek összehangolását jelentette. Mindenki, aki a fenntartható fejlesztés elméletével foglalkozik, illetve alkalmazni kívánja, elkerülhetetlen, hogy ismerje, illetve idézze a Brundtland jelentésben szereplő definíciót, miszerint a fenntartható fejlődés: ,a fejlődés olyan formája, amely a jelen igényeinek kielégítése mellett nem fosztja meg a jövő generációit saját szükségleteik kielégítésének lehetöségétöl" (Közös Jövőnk 1988, 68).

A Brundtland jelentésben olvasható definíció az 1994-es, Oslóban rendezett Symposium on Sustainable Consumption rendezvényre tovább bővuilt, $s$ a kỏvetkező meghatározással szolgált:

„A fenntartható termelés és fogyasztás a javak és szolgáltatások olyan felhasználása, amely lehetővé teszi az alapvető szükségletek kielégítését, az életminőség javítását, a természeti erőforrások felhasználásának, a mérgező anyagok, hulladé- 
kok és egyéb szennyezők kibocsátásának minimalizálásával, az adott életciklusban oly módon, hogy nem veszélyeztetik a jövő nemzedékek szükségleteinek kielégítését" (Simai 2001).

2002-ben Johannesburgban rendezett ENSZ Világcsúcs a Fenntartható Fejlödésröl újabb áttörést hozott a fenntartható fejlődés fogalmáról, azzal, hogy a szociálpolitikát is integrálta, s a fogalom így bővült ki: „az emberiség közös jövőjéről, annak a földi életközösségben való fenntarthatóságáról, olyan bolygóméretű tanulásifejlödési folyamatról beszélünk, amelynek eredményeképpen az emberi társadalom a Föld bolygón fenntarthatóvá válhat" (Láng 2002).

A különböző tudományterületek a fenntarthatóság feltételeivel foglalkoznak, mint például a kỏzgazdaságtudomány a fenntartható gazdasági növekedést vizsgálja, az ökológia a fenntartható környezetet, de valamennyi tudományág világosan látja azt, hogy a fenntarthatósảgra törekvés tudományterületek közötti egyuittmüködést követel meg.

Már 1992-ben elkészilit az Európai Közösség 5. Környezetvédelmi Akcióprogramja, mely az első átfogó és részletes dokumentum volt az Európai Közösség fenntarthatósági stratégiái közull (The Fifth EC Environmental Action Programme 1992).

Az Európai Tanács Göteborgi ülésén 2001 júniusában elfogadta a fenntartható fejlödés stratégiáját: „Fenntartható Európa egy jobb világért: az Európai Unió fenntartható fejlődésre vonatkozó stratégiája" (A Sustainable Europe for a Better World: A European Union Strategy for Sustainable Development), és környezetvédelmi dimenzióval egészítette ki a foglalkoztatás, a gazdasági reformok és a kohézió lisszaboni folyamatát. A stratégia négy kulcsprioritást fogalmaz meg: a klímaváltozással járó változások csökkentése és a megújítható energiaforrások növelése; az életminőségre ható veszélyek elhárítása; nagyobb felelösség a természeti eröforrások gazdálkodása területén; valamint a közlekedési rendszerek és a földhasználat javítása. A dokumentum úgy fogalmaz, hogy a fenntartható fejlödés legföbb akadálya az ủvegházhatást okozó gázok kibocsátása és a közlekedés által okozott környezetszennyezés ( $E C$ 2001). Ezeknek az akadályoknak a lekuizdése a közösségi politikákban olyan új megközelítést tesz szükségessé, amely közelebb hozza azokat az egyes polgárokhoz és vállalkozásokhoz, a fogyasztási és befektetési szokások megváltoztatása érdekében.

A fenntartható fejlődés interaktív fogalom, mely magába foglalja a gazdasági, társadalmi és ökológiai fenntarthatóságot. A fenntartható fejlődés ezen hármas tagolását a területfejlesztés és a vidékfejlesztés számára készült dokumentumok is átvették, illetve hangsúlyozzák.

A vidékfejlesztéshez közel álló agrárgazdaság számára a Kanadai Mezőgazdasági Minisztérium a következőképpen adta meg a fenntartható fejlődés definícióját: „Azokat nevezzük fenntartható mezógazdasági-élelmiszeripari rendszereknek, amelyek gazdaságosak, kielégítik a társadalom korszerú táplálkozással kapcsolatos igényeit, és megörzik a környezet minőségét, a világ természeti erőforrásait a jövő generációk számára" (Láng 2002).

2003 novemberében került sor Salzburgban a vidéki Európa jövőjével foglalkozó „Elvetett magok a rurális jövő számára - rurális politika perspektívái a tágabb 
Európaért" konferencia megrendezésére. A konferencia állást foglalt a fejlesztés alábbi három tengelye mentén:

1. versenyképesség a CAP reform elveinek érvényesítésén keresztül,

2. környezet- és tájgazdálkodás: támogatásokon keresztül növelni a környezet- és tájértéket, melyek kapcsolódjanak a Natura 2000-hez,

3. szélesebb vidékfejlesztés, azaz a rurális térségben élök életminőségének javítása, a gazdasági tevékenységek diverzifikálása, a sokszínủ rurális térségek vonzerejének a megtartása, a kulturális örökség megőrzése, és a helyi gazdaság valamennyi szektorának a támogatása.

A konferencia eredményeképpen meghatározásra kerültek az új programozási időszakra (2007-2013) vonatkozó legfontosabb prioritások, melyek a következök (Planting seeds 2003):

- a mezőgazdaság és az erdészet továbbra is meghatározó szerepet játszik a rurális táj és a életképes, fenntartható rurális közösségek számára;

- szélesebb rurális tér: a rurális területek fejlődése már soha többé nem alapulhat kizárólag a mezőgazdaságon, a diverzifikáció hangsúlyozása;

- az élelmiszerek minősége és biztonsága: Európa lakossága ragaszkodik a jó minőségü, egészséges élelmiszerhez, az állat-jóléti intézkedésekhez, és a rurális környezet megörzéséhez és értékeinek fokozásához;

- jobb elérhetőség a közszolgáltatásokhoz: az alternatív foglalkoztatottság hiánya, és a korstruktúra csökkenti a fejlesztési potenciált, föleg, ami a nök és fiatalok lehetöségeit illeti;

- koncentrálni az Európai Unió egész területén a CAP reform hatásaira, az átalakuló mezőgazdasági szektor kihívásaira;

- kohézió: EU vidékfejlesztési politikája már eddig is hozzájárult a kohézió erősítéséhez, de ezt a kibővített EU-ban fokozatosan erösíteni kell;

- aktív részvétel azok részéröl, akik alulról kezdeményező helyi fejlesztések szereplői kívánnak lenni, s a LEADER kezdeményezêst maguknak érzik;

- partnerség: a köz- és magánszféra közötti partnerség megvalósítása, mely nagy lehetőséget rejt magában arra, hogy hálózatokon keresztül megtanuljuk egymástól a legjobb példákat;

- egyszerüség: a vidékfejlesztési politika egyszerüsítése sürgős és szükséges.

Az így definiált prioritásokat a következö stratégiai megközelítéseken keresztül tervezik megvalósítani:

- új vidékfejlesztési alap létrehozása,

- stratégiai gondolkodásmód,

- programok megvalósítása,

- a fent nevezett három irány és azok intézkedéseinek következetes felépítése,

- LEADER modell folytatása és megszilárdítása EU szinten. 


\section{Európa rurális terei}

Az új funkciókkal rendelkező, folyamatosan változó és erösen differenciálódó rurális terek jellemzők egész Európában. Az utóbbi másfél évtizedben az európai rurális térben az alábbi jelentős változások történtek, melyek a post-produktivista átmenet szakaszára jellemzők (Ilbery 1998):

- a foglalkoztatottság és az élelmiszertermelés területén a mezőgazdaság szerepe csökken,

- nő a jelentősége a pluriaktivitásnak és a minőségi élelmiszertermelésnek,

- jellemző a szántóterületek folyamatos erdősítése, az erdészetnek a földhasználatban megváltozott a szerepe,

- a kis- és középvállalkozások térhódítása, a „high tech.” és szolgáltatóipar szerepe a foglalkoztatásban nő,

- jellemzö a rurális terek újfajta hasznosítása a kiskereskedelem, a turizmus, a rekreáció és a környezeti értékek megörzése terén,

- egyes rurális terek újranépesednek,

- a rurális térségekben élök között az életminöség területén egyre inkább fokozódnak a különbségek.

Az Agenda 2000 program elindította azt a vidékfejlesztési politikát, melyet a 2007-2013 programozási ciklusban bár óvatosan, de egyre jelentősebben teret nyer a korábbi agrárpolitikával szemben. Egészen 2000-ig a CAP-en belül a vidékfejlesztés részesedése a 8\%-ot nem tudta meghaladni, 2000-2006 között elérheti a 10,5\%-ot, s az új ciklus áttörést hozhat, mert a vidékfejlesztés aránya 15-16\%-ra nöhet.

Sokat beszélünk a vidék fejlődéséröl, fejlesztéséröl anélkül, hogy megpróbálnánk meghatározni azt. Mit akarunk fejleszteni, mit jelent az, hogy a ,vidék fejlődik"? A többféle definíció közül álljon itt három. Az OECD meghatározása szerint: A vidékfejlesztés ,....egy tágan értelmezhetỏ fogalom, mely figyelembe vesz minden fontos elemet a vidéki emberek és helyek életképességére vonatkozóan ... beleértve az oktatást, az egészségügyet, a lakást és lakhatóságot, a közszolgáltatást, annak infrastrukturális helyzetét, a kulturális örökséget, valamint a vezetés és a kormányzás kapacitását, de még az általános gazdasági és szektorális kérdéskört is" (OECD 1990, 23).

Kearney meghatározása szerint a vidékfejlesztés egy multidimenziós folyamat, amely arra hivatott, hogy fenntartható módon integrálja a gazdasági, társadalmikulturális és környezeti célokat (Kearney, Boyle, Walsh 1994, 128).

Moseley a vidékfejlesztést következőképpen definiálta: „A gazdasági, társadalmi, kulturális, politikai és környezeti változásoknak egy fenntartott és fenntartható folyamata, mely szándékosan megtervezett azért, hogy az egész közösség jólétét hosszú távon elösegítse. A fenti mondatban az egyes szavak jelentéstartalma a következő:

fenntartott: ami nem rövid életü, fenntartható: tekintettel van az örökségbe kapott „tökére”, folyamat: tevékenységek összefüggő rendszere, 
gazdasági: a javak és szolgáltatások termelésével, elosztásával és cseréjével kapcsolatos tevékenység, társadalmi: humán kapcsolatrendszerrel van összefüggésben, kulturális: az életúttal és az identitás forrásaival kapcsolatos, környezeti: természetföldrajzi környezettel kapcsolatos, hosszú táv: több tíz év, s nem pár év, jólét: nem csak anyagi gazdagság, egész közösség: értve alatta minden korosztályt, férfiakat, nőket és az összes társadalmi csoportot, azon az adott helyen, ahol élnek és/vagy dolgoznak " (Moseley 2003, 4).

Az Európai Unió rurális térségeinek fejlesztési modellje már nem nevezhető egyszerüen vidékfejlesztésnek, annál több, ez a modell a közösségen alapuló integrált vidékfejlesztés modellje (Community based Integrated Rural Development: CIRD). Integrált,

- mert a fejlesztés a társadalom, a gazdaság és a környezet együttes, azonos súlyú kezelésén alapul,

- mert a fejlesztésben a „bottom-up” politika érvényesül, hiszen a helyben élők saját forrásaikkal (beleértve az anyagit is) és elkötelezettségeikkel felelősen támogatják a helyi programokat, de beépítik a vertikális intézményrendszerbe a ,top-down" elemeket is azzal, hogy a központi vagy regionális kormány részéről közvetített politikát elősegítik, a pénzügyi támogatások pedig serkentik a fejlödést,

- mert a fejlesztés multiszektorális, mert valamennyi szektor a közszolgáltatási, a magán és a civil szféra is részt vesz benne,

- mert a fejlesztés teljes folyamata széles partnerségen és együttmüködésen alapul.

A közösségen alapuló integrált vidékfejlesztés (CIRD) legföbb ismérvei:

1) A lokalitás, vagyis a kistérségi szint elötérbe helyezése.

2) A felelősség és a hatalom átruházása, vagyis a szubszidiaritás érvényesítése.

3) A helyi diverzitás fontosságának hangsúlyozása.

4) A top-down és bottom-up politikák összehangolása, azaz az alulról jövő kezdeményezéseknek és megvalósításuknak a vertikális intézményrendszerbe való beépítése.

5) A helyi közösségek minél nagyobb mértékü bevonása a megtervezett folyamatba.

6) A helyi identifikáció: a helyi szereplők aktivitásának előmozdítása, a társadalmi tőke feltárása és mobilizálása, és a helyi tudás és gyakorlat alkalmazása a programok kidolgozására és megvalósítására.

7) A helyi eröforrások szükséges ismerete, és alapos elemzése a fejlesztésbe való bevonásának érdekében. 
8) A helyi erőforrások értékének növelése a hozzáadott értéken keresztül, mely biztosítja a helyi gazdaság nagyobb biztonságát, és a fenntarthatóságát.

9) A kis- és középvállalkozások számának és kapacitásának növelése.

10) A rurális térségek újfajta hasznosításának előmozdítása, mint a rurális turizmus fejlesztése, valamint a természeti és kulturális örökség védelme és helyes piacosítása.

11) A globalizációval szembeni védelem, mert a globalizáció azzal jár, hogy miközben egyre inkább nyitottá válik a helyi gazdaság, aközben egyre inkább kiszolgáltatottabbá válik a gazdasági versenyben. A modern információs és kommunikációs technikák alkalmazásából, a nemzetközi tőkemozgásokból, a multinacionális cégek erösségéböl következően nyomás nehezedik rá, mely megmutatkozik a termékek árának alacsonyabb voltában, melyet még az is fokoz, hogy a társadalmi és környezeti megszorítások gyengébbek. Mindez veszélyezteti a helyi, különösen a kevésbé fejlett térségek gazdaságát, $s$ ezen keresztül társadalmát, lakosságát, vagyis az adott rurális tér életképességét, fejlödö képességét. Erre válaszképpen hangsúlyozni kell és fel kell hívni a figyelmet a helyi egyediségre, és erősíteni kell a helyi identitást, a helyi minőségi termékeken és szolgáltatásokon keresztül, ami már elvezet a kultúra gazdaságához.

Az európai rurális terek egyre differenciáltabbak, s az egymástól eltérő rurális terekben, melyek nem csak térben és idöben változnak, hanem különböznek diverzitásukban, mobilizációjukban, identitásukban, erőforrásaikban, de még a globalizációval szembeni magatartásukban is, a fejlesztésükre szükségszerüen más eszközöket, más politikákat kell alkalmazniuk.

Nagy-Britanniában még 1988-ban a Gazdasági és Társadalmi Kutatások Tanácsa (ESRC) finanszírozta azt a kutatást, melynek keretében felállították a „differenciált vidék" téziseit, és foglalkoztak az egyes típusok jellemzöivel (Murdoch-Lowe-WardMarsden 2003). A brit kutatási eredmények a társadalmi összetétel vâltozásából és a helyi társadalom konfliktus- szituációiból vezetik le az alábbi négy rurális típust.

1. Megörzött vidék (preserved countryside): ezek a vidéki területek kapcsolódnak legszorosabban a rurális idillhez, a fejlesztés visszafogásával egy idöben a környezet állapotának konzerválásán van a hangsúly. Mivel az urbánus térségekbỏl könnyen megközelíthetök, azaz jó elérhetőségüek, ezért lakosságuk jelentős része a városokból kitelepült középosztályhoz tartozik, akik a helyi politikai befolyásukon keresztül saját maguknak kívánják megőrizni a térséget az eredeti mivoltában, saját maguk számára kívánják megvédeni az eddig megszerzett javaikat. A fentiekből kovetkezik, hogy a pihenésüdülés, a környezetmegörzés, a szolgáltató szektor és a lakóingatlanokra vonatkozó fejlesztések kerülnek előtérbe.

2. Konfliktusokkal terhelt (küzdö) vidék (contested countryside): ezek a területek távol esnek a szuburbán területektől, nem jellemző rájuk az ingázás, ezért az itt élők érdeke sokkal inkább a lokális mezőgazdaság és a kereskedelem fejlesztése. Ezzel az irânyvonallal viszont egyre inkább szembe 
állnak a betelepülők: a középosztályhoz tartozó alkalmazottak, nyugdijasok érdekei, akiket többnyire éppen ez a lakókörnyezet vonz, akiknek itt éppolyan érdekeik vannak, mint az előző kategória betelepülőinek, de érdekeik érvényesítéséhez nincs elég erejük. Így a két társadalmi csoport között növekvő konfliktus feszül, s egyetlen közös érdek sincs, ami ezt tompíthatná.

3. Paternalista (gyámság alatti) vidék (paternalistic countryside): ehhez a kategóriához tartozó területeken a nagykierjedésủ birtokokon folyik a gazdálkodás, ebböl következỏen a fejlesztés jövőjén a földtulajdonosok és/vagy földhasználók örködnek. A CAP reform kapcsán a tradicionális termelés esetén szembesülnek csökkenó jövedelmükkel, s ennek kompenzálására új jövedelemforrásokat keresnek, $\mathrm{s}$ a diverzifikáció irányába lépnek, $\mathrm{s}$ az ehhez szükséges fejlesztéseket gyakorlatilag akadálytalanul képesek megvalósítani. Mindez azt jelenti, hogy a fejlesztések elsősorban a földtulajdonosok/földhasználók érdekeit szolgálják. Az alulról jövő kezdeményezések jobban elsikkadnak, a fejlesztés széles társadalmi támogatottsága kisebb.

4. Klientista (államtól függö) vidék (clientistic countryside): periférikus, távol eső vidéki területek sorolhatók ebbe a kategóriába, ahol a mezőgazdaság szerepe meghatározó, és az államhoz tartozó fejlesztési ügynökségek, politikák és intézkedések határozzák meg a terület fejlődését. Többnyire a kívülről jövő beruházások az állami segélyektől függnek, a helyi fejlesztések a foglalkoztatási politikára és a szociális intézkedésekre koncentrálnak.

Attól függően, hogy a fejlesztés kezdeményezését mely szektor, vagy a táradalom mely rétege ragadja magához, más-más megközelítést, más-más súlyozást kap a fejlesztés maga.

„A helyi fejlesztés több, mint az olyan beavatkozások sorozata, melyek a központi poiitika által szervezettek .... egy olyan alapvető reakció, mely megkísérli elérni az új célokat a fejlesztés folyamatában olyan fogalmakra összpontosítva, mint a multidimenzionalitás, az integráció, a koordináció, a szubszidiaritás és a fenntarthatóság (Moseley 2003, 7).

A rurális terek erős differenciációja szerepet játszott abban, hogy a kilencvenes években a vidék fejlesztésének a fent említett jellegzetes európai modellje alakuljon ki, ami a helyi fejlesztést helyezi előtérbe a bottom-up politika alkalmazásával. Az előzőekböl már levonható, hogy helyi konszenzuson alapuló fenntartható vidékfejlesztés csak a helyi társadalom erỏsítésével, érdekérvényesítő képességének fokozásával lehetséges. Ha pedig így lehetséges, akkor a stratégiák kialakításánál be kell tervezni az olyan technikák alkalmazását, melyek a fentieket erősítik.

\section{Magyarország rurális térségeinek jellemzői}

Magyarországon a rendszerváltás okozta sokk negatív hatásai a rurális területeken kulminálódtak. A hátrányok többszörösen jelentkeztek az ország magterületeihez, nagyvárosaihoz képest, mert az ipari szerkezetváltással járó problémák, az ebböl 
adódó, hirtelen az országra rázúduló ipari válsághelyzet, majd az ezt követő munkanélküliség elvonta a politikusok figyelmét a rurális térségekröl. A vidék civil társadalma, mely különösen gyenge volt a falvakban, nem volt képes az ott élők érdekeinek érvényesítésére.

Az átalakuló gazdaság és az ezzel járó mezőgazdasági válság mélyítette a rurális térségekben az átmenet nehézségeit, erösítette a gazdaság negatív folyamatait. Magyarországon már régóta nem lehet a vidék gazdaságát a mezögazdasággal azonosítani, így a vidék fejlesztését sem az agrárfejlesztéssel. Mint Illés Iván íta: „Sokszor és sokáig azonosították a falu és a város dichotomiáját a mezőgazdaság és ipar dichotómiájával, holott ez így teljes mértékben soha és sehol nem volt igaz, és különösen nem a huszadik század második felében" (Illés 1993, 36). Mégis, a vidék diverzifikált gazdaságának nélkülözhetetlen pillére a mezögazdasági szektor, melynek az áru- és jövedelemtermelése a rendszerváltást követően folyamatos és meredek csökkenést mutatott, jellemző volt továbbá a vagyonvesztés, az érdektelenség is (Kiss 2002).

Az agrárszektorban foglalkoztatott munkaerö tíz év alatt (1990-2000) 561 ezer fövel csökkent, növelve ezzel a rurális munkanélküliséget és elszegényedést. Ilyen gazdasági körülmények között sokszorozódott meg a földtulajdonosok száma, és aprózódott el a földtulajdon a kilencvenes évek első felében lezajlott földprivatizáció során.

Magyarország GDP szerkezete az EU tagországok GDP szerkezetéhez közelít ugyan, de amíg voltak országok, melyek az ezredfordulón még növelték is (Görögország) a mezőgazdaság részesedését, addig Magyarországon ez az érték folyamatosan csökkent (Kovács 2002). Nálunk a mezögazdasági, az erdö-, vad- és halászati szektor egyuitt a GDP 13\%-át tette ki még 1990-ben, de a kilencvenes évtizedben ez az érték rohamosan csökkent (1. táblázat), amit jelentös mértékben követett a mezőgazdaságból származó jövedelem csökkenése is.

\section{TÁBLÁZAT}

A mezögazdaság, vadászat és az erdészet részesedése a bruttó hozzáadott értékböl folyó áron, 1990-2001, Magyararszágon

(Agruculture, Hunting and Forestry from the Gross Value Added at Current Prices, 1990-2001, in Hungary)

\begin{tabular}{|c|c|c|c|c|c|}
\hline & 1990 & 1995 & 1999 & 2000 & 2001 \\
\hline $\begin{array}{l}\text { Mező-, vad, erdógaz- } \\
\text { dálkodás és halászat } \\
\text { (millió Ft) }\end{array}$ & & 332963 & 483522 & 490886 & 562712 \\
\hline $\begin{array}{l}\text { Mező-, vad, erdőgazdál- } \\
\text { kodás és halászat (\%) }\end{array}$ & 13,7 & 6,75 & 4,85 & 4,28 & 4,30 \\
\hline $\begin{array}{l}\text { Nemzetgazdaság } \\
\text { összesen (millió Ft) }\end{array}$ & & 4932855 & 9973026 & 11482673 & 13090637 \\
\hline $\begin{array}{l}\text { Nemzetgazdaság } \\
\text { összesen }(\%)\end{array}$ & 100 & 100 & 100 & 100 & 100 \\
\hline
\end{tabular}

Forrás: Magyarország nemzeti számlái 1995, KSH Budapest 1995, Magyarország nemzeti számlái 2000-2001, KSH Budapest 2003. 
Szörényiné Kukorelli Irén : A fenntartható fejlödés stratégiai elemei a rurális térségekben.

Tér és Társadalom 19. évf. 2005/3-4. 111-137. p.

TÉT XIX. évf. 2005 『 3-4

A fenntartható fejlödés...

A földprivatizáció majdnem teljes befejezése után, ma Magyarországon közel kétmillió földtulajdonos van, s az átlagos birtokméret az OECD 1999-es adatai szerint három hektár, az összes tulajdonos 11\%-a 1 hektárnál kisebb földtulajdonnal, s 60\%-a 10 hektárnál kisebb a földtulajdonnal rendelkezik. Már ebből is következik, hogy a földtulajdon és a földhasználat kettévált. Az átalakult tulajdoni szerkezet mellett az üzemi szerkezet is megváltozott (2. táblázat).

2. TÁBLÁZAT

A földterïlet gazdálkodási formák szerinti megoszlása 1990-2000 között Magyarországon (1000 ha)

(Land Areas by Agricultural Enterprice Forms in Hungary 1990-2000 [1000 ha])

\begin{tabular}{|c|c|c|c|c|}
\hline \multirow{2}{*}{$\begin{array}{l}\text { Gazdálkodási } \\
\text { formák }\end{array}$} & 1990 & 1994 & 1996 & 2000 \\
\hline & \multicolumn{4}{|c|}{$1000 \mathrm{ha}$} \\
\hline Gazdasági társaságok & 2150 & 3086 & 2615 & 2561 \\
\hline Szövetkezetek & 4938 & 2726 & 2010 & 1230 \\
\hline Egyéni gazdálkodók & 560 & 2074 & 3152 & 3983 \\
\hline Lakosság egyéb csoportjai & 1655 & 1416 & 1526 & 1529 \\
\hline Összesen & 9303 & 9303 & 9303 & 9303 \\
\hline
\end{tabular}

Forrás. Magyar Statisztikai Évkönyv 1995-2000, KSH.

Az egyéni gazdaságok száma, melyek valamely mezőgazdasági tevékenységgel foglalkoznak: 958 534, a gazdasági szervezetek száma 8382 darab'. Az egyéni gazdaságok általános birtokmérete 4,15 ha, míg a gazdasági társaságok és szövetkezetekre átlagosan bỏ százszorosa jut, 452,3 ha. Ezek a számok már önmagukban bizonyítják a mezőgazdasági szektor megosztottságát, és jelzik a gazdálkodás feltételeinek nagy amplitúdóját, mely a falusi társadalom foglalkoztatására, jövedelemszerzésére és a vidéki terek jövőére van kihatással. A mezőgazdasági versenyszféra és az önellátó, kiegészítỏ jövedelmet adó, ,,szociális mezőgazdaság” egymástól elkülönült, azaz nálunk is egyszerre van jelen a produktivista és a postproduktivista, talán helyesebben: a nem piacképes mezőgazdaság, de az utóbbi megjelenése legföképp nem a fejlödés következő lépcsőfokaként jelentkezik (bár erre is vannak jelek Közép- és Nyugat-Magyarország példáján), hanem éppen a privatizációból adódó birtokaprózódásnak a következménye. Ez pedig a szegénység újratermelése. Az ilyen életképtelen gazdaságok száma az Észak-Alföldön és a DélDunántúlon alig változott, a Közép-magyarországi régióban való csökkenésük a gazdasági szféra más szektorainak megerősödését jelzi. Mindez arra utal, hogy a versenyképes mezőgazdaság el fog különülni a nem piacképes mezőgazdasági termeléstől, azaz lesz (már van) olyan régió (táj, körzet, vidék stb.), ahol a mezőgazdaság a legfontosabb és versenyképes ágazat lesz, ma az ország szántóterületének mintegy 70\%-án gazdálkodó egyéni és társas gazdaságok esetében várható ez, amelyek száma ma alig több 30-35 ezer. Számos olyan térség van, ahol a mezőgazdaság 
Tér és Társadalom 19. évf. 2005/3-4. 111-137. p.

alárendelt jelentőségü, nem piacképes. Ez utóbbi esetben a vidékfejlesztés feladatai, annak is társadalmi aspektusai kapnak nagyobb hangsúlyt.

Az erdögazdálkodás a vidéki gazdaság tradicionális ágazata. Ma a földterület 19\%-át borítja erdő, azaz a szántóterületek után a második legnagyobb területet foglalja el. Az 1996-os erdőtörvény szerint az erdỏ védelmi, gazdasági, egészségügyiszociális, turisztikai, oktatás-kutatási funkciókkal rendelkezik. A rendszerváltás után az erdőterületek privatizálásával és a magán erdötelepítésekkel megváltozott a társadalomnak az erdőhöz való kapcsolata. Ma mintegy 250 ezer erdőtulajdonos van Magyarországon. Az erdőtelepítés eddigi trendje szerint elérhető az erdösültség 25-27\%-ra való kiterjesztése. Az erdőgazdálkodás a fakitermelésen és a magán erdőtelepítésen keresztül fontos eleme a fenntartható vidékfejlesztésnek, emellett a természetközeli erdőgazdálkodás a fenntartható rurálturizmusnak és az ökoturizmusnak az egyik vonzereje.

Ma még alig emlegetjük a védett területeken, nemzeti parkokban történó gazdálkodást, de jelentősége, a gazdaság diverzifikációjában betöltött szerepe már a közeljövöben nö. Az országban tíz nemzeti park müködik, kereken 485 ezer ha-on, tájvédelmi körzetek területe 310 ezer ha, természetvédelmi területek 26 ezer ha, helyi védettségü területek 37 ezer ha. Ezek és pufferzónájuk potenciális területei a tájgazdálkodásnak és a rurálturizmusnak. Jelenleg a védett területek konfliktusforrások a park hatósága és a falvak lakossága és gazdálkodói között. A közeljövőben az érdekellentétek feloldására, új támogatási rendszer kidolgozására és életbe léptetésére van szükség a környezeti tervezés és gazdasági hasznosítás egyensúlyának megtalálása és alkalmazása érdekében.

A vidéki térségek gazdaságában a fenti szektorokon kívül az ipar és a szolgáltatás is jelentős szerepet játszik. Mind az EU, mind a hazai vidékfejlesztési politika hangsúlyozza a vidéki kis- és középvállalkozások megtelepedésének és müködésének fontosságát a vidéki gazdaság jövedelemképességének fokozása érdekében. Magyarországon ebben is rendkívül nagy különbségek mutatkoznak, míg NyugatDunántúlon, különösen az osztrák határ menti falvakban gyakoriak a külföldi tőkével alapított, az ipari szektorhoz tartozó kis- és középvállalkozások, addig országos szinten a vidéki térségekben számuk alacsony.

Igazi jövedelem-kiegészítésúl szolgálhat a kilencvenes évektől újra elinduló falusi turizmus tevékenység. A falusi turizmusfejlesztés mind országosan, mind kistérségi szinten fejlesztési lehetőségként, programként jelent meg a különböző területfejlesztési, vidékfejlesztési dokumentumokban már a kilencvenes évek első felében. Az 1990 elött már müködö falusi turizmus tevékenység föleg a tradicionális üdülöterulletekhez kötődött, mint például a Balaton térsége. Megjelent és fejlődöben van egy új kínálat, mégpedig a falusi idillt nyújtó kistelepülések, valamint a háborítatlan természetet, a természeti örökséget kínáló természetvédelmi térségek, nemzeti parkok, natúrparkok területein és közvetlen szomszédságukban található települések. Ez utóbbi csoporthoz tartozók számára a turizmus megteremtésének feltételei, az infrastrukturális adottságok hiányosak voltak, vagy egyszerủen hiányoztak. Mára a falusi turizmus ezekben a régiókban tudta növelni a férőhelyek számát, és ennek 
következtében mind a vendégek száma, mind vendégéjszakák száma emelkedést mutat. A falusi turizmusból jövedelmet remélők ma már eljutottak addig, hogy nem csak szállásokat, hanem a programokat is ajánlják vendégeiknek. Meg kell jegyezni, hogy a falusi turizmus kiegészító jövedelemként szolgálhat, hozzájárul a rurális térségekben a diverzifikált jövedelemtermeléshez. Lényeges különbség, hogy míg Nyugat-Európában és például Lengyelországban a falusi turizmus a farmgazdaságok diverzifikáciojához járul hozzá, addig nálunk sokkal inkább a falusi, de nem feltétlenül mezőgazdasággal foglalkozók vállalják fel ezt a tevékenységet, növelve ezzel a falusi gazdaság diverzifikációját (Momsen-Szörényiné Kukorelli 2005).

Az ipari szerkezetváltás folyamata, a mezögazdasági szektor és a termőföld privatizációja a falusi, kisvárosi, vagyis a rurális terek gazdaságára, a foglalkoztatottságra negatívan hatott, s a felszínre törő rurális munkanélküliség egyik meghatározó okává vált.

A rurális munkanélküliség növekedésének a helyi gazdaság és/vagy a közeli foglalkoztató központ gazdasági szerkezetváltása volt az egyik, a TSZ melléküzemágak megszünése és a TSZ-ek felbomlása volt a másik összetevője. A falun élök és munkahelyüket elvesztök csoportjához tartoztak azok, akik lakóhelyükre tértek vissza, mint volt ingázók, azok, akiknek a lakóhelyén megszünt az ipari telephely, mint a falusi ipar reprezentáns eleme, $\mathrm{s}$ azok is, akik a termelöszövetkezet melléküzemágának bezárása miatt váltak munkanélkülivé, $s$ azok is, akik a termelöszövetkezet felbomlása révén váltak azzá. Így lehetett az, hogy a regisztrált munkanélküliekre vonatkozó munkanélküliségi ráta a falvakban (17,5\%), mintegy háromszorosa volt a budapesti (5,3\%), s kétszerese a megyeszékhelyi értéknek (9,8\%) 1992. év közepén (Lehota 2003).

Az állami gazdaságok és a TSZ-ek leépülésével, felbomlásával és privatizációjával járó foglalkoztatási gondokat, a fellépő munkanélküliséget a tőkeszegény, lassan kiépülő és piacot kereső magángazdaság nem tudta megoldani. Mindehhez még azt is figyelembe kell venni, hogy a falusi népesség átlagos iskolázottsági szintje alacsonyabb, több közöttuik a fizikai dolgozó. A munkanélküliek közel fele a nyolc általánossal vagy annál alacsonyabb iskolai végzettséggel rendelkezök közül került ki, ez önmagában már a falusi népességet magasabb arányban érintette. A falusi munkanélküliség területileg is differenciálódott, és magasabb értéket mutatott egyes térségekben, mint például Észak-Magyarországon, az ipari depresszióval sújtott területen (Bognár-Imre-Mezei 2001).

A trendek - különösen a falvak és városok munkanélküliségi rátája közötti különbséget, valamint az ország regionális különbségeit illetően - nem változtak. Ma is magasabb a falusi térségek munkanélküliségi rátája, rosszabb a foglalkoztatottsági szint. Magyarországon a falvakban élő aktív korú lakosság száma 2,3 millió, de az aktív korú lakosságnak még a fele sincs foglalkoztatva. A munkahelyi lehetőségek nagy területi differenciákat mutatnak. Míg a Bécs-Budapest tengely mentén jóval nagyobbak az esélyek a foglalkoztatásra, addig az Észak-magyarországi és az Észak-alföldi régió vidéki térségeiben, valamint a Dél-Dunántúlon már-már kilátástalan a helyzet. A falvakban, föleg a törpe és aprófalvakban a foglalkoztatás szintjének 
emelése, munkahelyek teremtése a legnehezebb feladat. Ezekben a falvakban legtöbb esetben egyetlen foglalkoztató maga az önkormányzat. De nem csak a falvak, hanem egyes térségek is kritikus szintet értek el a foglalkoztatás területén, és a munkanélküliség is leképezi a „nyugat-keleti lejtőt”. „A vidéki térségeket sújtó magas munkanélküliség rendkívül stabil térszerkezetủ, az elmúlt másfél évtizedben alig történtek jelentősebb elmozdulások. A rossz foglalkoztatási helyzet tehát az egész 'vidéki Magyarország' összetett gyökerủ elmaradottságának egyik legfontosabb következménye, ugyanakkor tartóssá válása, illetve a munkanélküliek tömeges megjelenésének következményei (társadalmi devianciák, elszegényedés stb.) miatt maga is az elmaradottság egyik fö tényezöjévé, strukturális elemmé vált" (Csatári 2004, 32). Tény, hogy a jelenlegi foglalkoztatási struktúra vetületét a fỏldrajzi helyzet, valamint a történelmi és kulturális tradícióik alakították, és a rendszerváltás csak erösítette.

A rendszerváltás után szembesülni kellett azzal a ténnyel, hogy az államszocializmus egyik legnagyobb hibája a vidéki térségek infrastrukturális elhanyagoltsága volt. A rendszerváltozás után, már a kilencvenes évek elsỏ felében a vidéki (falusi, kisvárosi) települési önkormányzatok egyik első, szívesen magukra vállalt feladata volt a mủszaki infrastruktúra elemeinek a kiépítése. Több helyen még az ivóvízhálózat is kiépitésre szorult, de elindult a csatornahálózat, a gázvezeték és a telefon építése is, a szemétgyüjtés és elhelyezés megszervezése. Az infrastrukturális fejlesztések bizonyos mértékig átgondolatlanok voltak, különösen, ami a fenntartható fejlödésre való odafigyelést jelenti. Épültek gazdaságtalan szennyvíztisztítók az aprófalvakban, megtörtént a gázfütésre való áttérés, amely sok esetben az önkormányzatok és a lakosság teherbíró képességét meghaladta. A drága műszaki infrastruktúra megteremtését sajnálatos módon, éppen a fentiekben felvázolt gazdasági és foglalkoztatási krízishelyzet miatt a gazdaság élénkülése nem követte, aminek következtében az infrastruktúra fenntartása, müködtetése egyre nagyobb terhet jelent mind az önkormányzatnak, mind a lakosságnak. Az erőltetett hulladékgyüjtés bevezetése szintén nem jelentett előrelépést a fenntartható fejlesztés felé, hiszen szelektív hulladékgyüjtés helyett a válogatás nélküli hulladékgyűjitést rendelték el a falvakban is, s egy újratanulási folyamatra van/lesz szükség a szelektív hulladékgyüjtés bevezetése esetén.

A közlekedés színvonala, az elérhetőség minősége a vidékfejlesztés alapfeltétele. A közlekedési elérhetőség javításával a gazdaság élénkülése, a társadalom kohéziója érhetó el.

A szociális infrastruktúrához sorolhatóak az iskolák, idősek számára szolgáló klubok és otthonok, óvodák, egészségügyi intézmények. Az iskolák helyreállítását, mely a kilencvenes évek elsỏ felében a kistelepülések önkormányzatainak nagy feladatai voltak, nem elózte meg népesség-előjelzési prognózis, ami egyik oka a bö tízéves mủködés ellehetetlenülésének az aprófalvakban.

Összességében a vidéki térségek infrastruktúra fejlesztése alapkövetelmény, de kiépítésénél és bővítésénél sokkal jobban figyelni kellene a gazdasági és társadalmi fenntarthatóság kritériumaira.

A rendszerváltást követỏen, 1991-ben lépett életbe az önkormányzati törvény, amelynek hatására a korábbi közös tanácsokhoz tartozó településcsoportok bomlottak 
fel, izolálódtak a települések. Önállóan kívánták megoldani az önkormányzati törvény által elöírt és még az önként magukra vállalt feladatokat is, a „függetlenség érzésének” eufóriájával pótolva' a szétaprózott erőforrásokat, s a forráshiányt. A kilencvenes évek elején a helyi fejlesztések színtere az önálló önkormányzati testülettel rendelkező falvak voltak. A polgármesterek - látva és érezve a kistelepülések önkormányzatainak érdekképviseleti és érdekérvényesítési nehézségeit és az infrastruktúra fejlesztés területén szükséges beruházások összehangolását - az összefogás jeleit mutatták. Elindultak a települések közötti kistérségi együttmüködések, s a helyi fejlesztés, a közösségen alapuló integrált vidékfejlesztés egysége egyre inkább a kistérségi szintre tevödött át. Erre a szintre készülltek el a SAPARD programra való felkészülés folyamatában a kistérségi vidékfejlesztési stratégiák, majd a SAPARD kistérségekben a vidékfejlesztési menedzser foglalkoztatása is központi forrásból biztosított lett. Viszont a SAPARD vidékfejlesztési kistérségek térlefedettsége különbözött a KSH kistérségi besorolástól. Erre a beosztásra nem készült statisztikai elemzés, viszont a KSH által kijelölt kistérségek váltak a területfejlesztés beavatkozási szintjévé. Az elmúlt évek folyamatai arra utalnak, hogy ezt a szintet kívánja mind a területfejlesztés, mind a vidékfejlesztés beavatkozási szintként kezelni, a többcélú kistérségi társulások már e célból alakultak meg. Kormányzati szinten a kistérség és szervezetének újragondolására 2003-ban és 2004-ben egy 3 lépcsős reform folyamat indult el. Harmadik lépcsöben került sor a területfejlesztési törvény 2004 júniusában elfogadott módosítására, benne a kistérségi szint megerősítésére. A többcélú kistérségi társulás formáció létrehozásával lezárult egy korszak. A korábbi funkcionális kistérségek, de még a vidékfejlesztési (SAPARD) kistérségek is elvesztették létalapjukat. Nincs olyan pályázati forrás, mely a korábbi, nem KSH kistérség alapon szerveződött önkormányzati területfejlesztési társulásokat támogatná.

A KSH kistérségre vonatkozó statisztikai vizsgálatok alapján, mely a Csatári vezetésével elkészült „Magyarország új vidékfejlesztési tézisei” anyagban érhetők el, lehatárolásra kerültek a rurális típusú KSH kistérségek (1. ábra).

„A $168^{2}$ jelenleg érvényes beosztású kistérségböl - a 120 fö $/ \mathrm{km}^{2}$-es népsürủség és a népesség ezen értéke alapján számított települési koncentrációja szerint - 100 „vidékiesnek” tekinthető kistérség található hazánkban (ez a kistérségek 59,2\%-a). Összesen 1813 település tartozik hozzájuk (a települések 57,8\%-a), területük 57 ezer $\mathrm{km}^{2}$, a lakónépességük a 2001-es népszámlálás szerint 3,3 millió fö (részesedés a 8,4 millió lakosból $39,7 \%$ ). Ha az e tekintetben nem vidékies kistérségek besorolását tovább „finomítjuk”, akkor megállapítható, hogy további 41 olyan városias térség van, ahol különböző vidékies tényezők (pl. aprófalvas, tanyás, mezővárosias jelleg) kiemelhetően megjelennek" (Csatári 2004, 47).

A KSH kistérségek tipizálása alapján rurális kategóriába besorolt kistérségek a településszerkezet alapján jelentős különbségeket mutatnak, mert egymástól jól elkülönülnek az aprófalvas településszerkezetủ és a tanyás kistérségek (2. ábra). Mindegyik rurális jellegü, de fejlesztésük teljesen különböző beavatkozásokat igényel. 
Szörényiné Kukorelli Irén : A fenntartható fejlödés stratégiai elemei a rurális térségekben.

Tér és Társadalom 19. évf. 2005/3-4. 111-137. p.

OMTA RKK ATI, Keeskeme

\section{1. ÁBRA}

KSH kistérségek típusai

(Types of Small Regions Defined by CSO)

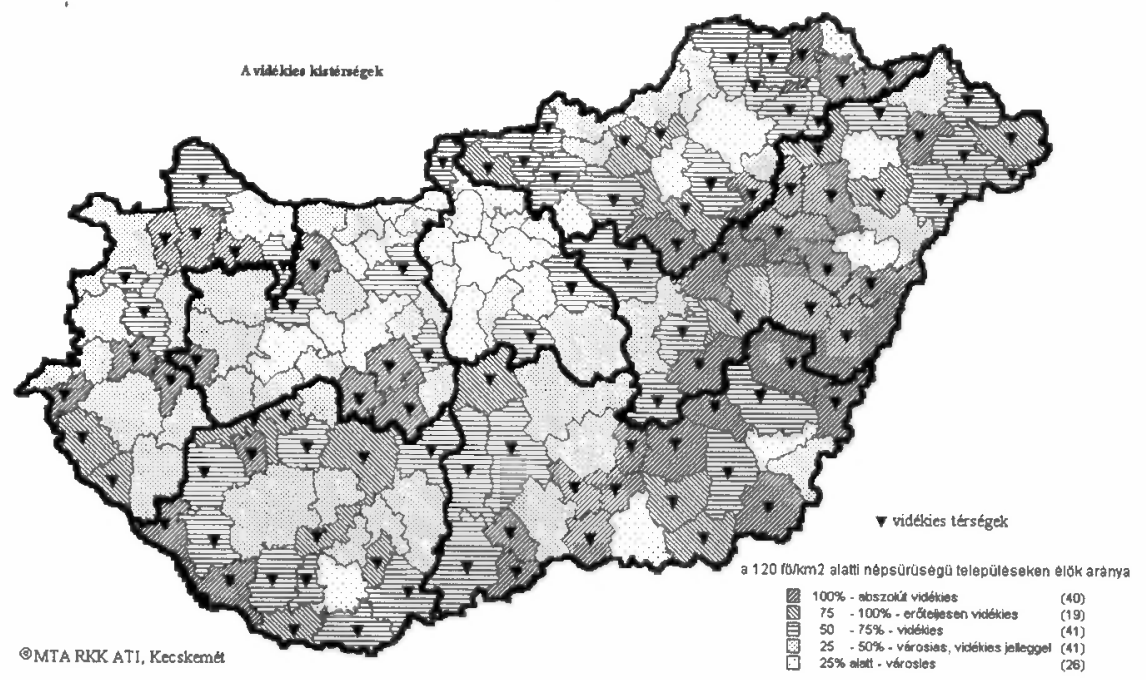

Forrás: Csatári 2004.

\section{2. ÁBRA}

Aprófalvas kistérségek

(Small Regions with Small Size Villages)

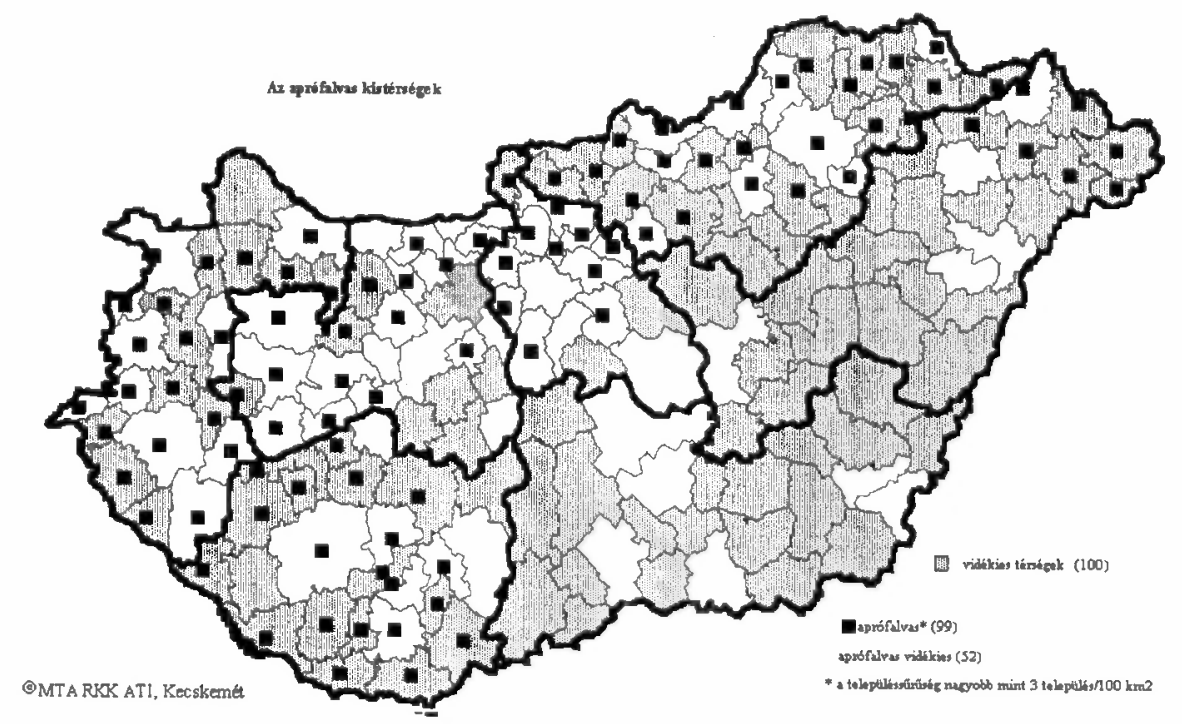

Forrás: Csatári 2004. 
A rurális jellegú kistérségek területi megoszlását a fenti két ábra világosan mutatja be, de figyelembe kell venni, hogy egyes kistérségeken belül is nagy differenciák mutatkoznak, másrészt önmagában a rurális jelleg és a fejlettség egymást nem kizáró fogalom. A vidék civil szervezödései gyengék és kis számúak, így az érdekérvényesítés gyenge pontja a vidéki társadalomnak. A rendszerváltás hajnalán adódott lehetőség arra, hogy a civil szervezetek újra éledjenek, 1987-től lehetőség nyílott alapítványok létrehozására, majd az 1989-es ún. egyesülési törvény már megengedte az egyesületek és egyéb társadalmi szervezödések müködését és alapitását, újra kellett építeni a helyi civil szférát. Az államszocializmus időszakában a korábban a falusi társadalomban mủködö egyesületek, társaságok, egyletek és körök gyorsan felszámolódtak. A nyolcvanas évek végén, a kilencvenes évek elején a negyven éves változáson átesö vidéki társadalomnak újra kellett tanulni a civil szervezödések megteremtését és azt a szerepet, mely egy civil szervezödés müködésével, mủködtetésével jár. Ezt egy olyan közegben kellett újra tanulni, mely már nagyon elszakadt a korábbi évtizedek hagyományos vidéki társadalmától. A vidéki településekben, különösen a centrumoktól távol eső aprófalvas területeken a népesség elvándorlása miatt elindult a népességerózió folyamata, a helyi értelmiség kiürülése. Az ilyen állapotokat öröklő helyi társadalomban hiányoznak azok a helyi indukciók, melyek a motorjai lehetnének a civil szféra életre keltésének.

A vidéki térségekben müködő civil szervezetek elsősorban az adott településhez, faluhoz kötődnek. A faluhatárokat átlépő szervezödések a kistérségi szinten még a kilencvenes évek elején megalakult fejlesztési társulások, alapítványok, egyesületek voltak. Ezek a szervezetek voltak a vidékfejlesztés intézményeinek első alulról jövő kezdeményezései. A kistérségi szerveződések a mindenkori település önkormányzat vezetỏinek, polgármestereinek egymás közötti személyes jó kapcsolatait, a lehetséges együttmüködés tereit tükrözték. A kistérségi szerveződés egyik formája az önkormányzati területfejlesztési társulás, mely szerepel a területfejlesztési törvény (1996/21. tv.) III. fejezetében ,a területfejlesztést és területrendezést ellátó területi szervek" között. Ezzel mintegy a korábban elindult kistérségi szerveződések ezen formája került legalizálásra, s vált 1996 után leginkább elfogadott formává. A 96/21. törvény érdeme volt, hogy felgyorsította a kistérségi szerveződéseket, összefogásra inspirálta a települési önkormányzatokat, és lehetőséget biztosított nekik a megyei területfejlesztési tanácsban való képviseleten keresztül a döntésekben.

Ezek az együttmüködések magyarországi minta és tapasztalat nélkül formálódtak, létrehozva a funkcionáló kistérséget. Megmaradásukat, müködésüket, eddig elért eredményeiket az alulról építkezés magyarázza, erejuk a helyi döntéshozók tenni akarásában rejlett. Egyre teljesebb munkát képesek végezni, pályázatok útján forrásokat képesek biztosítani önmaguknak, projekteket menedzselni, megvalósítani. Mindez nem jellemzỏ általánosan a kistérségi szintre, csak egyes kistérségi társulásokra, azokra, ahol a lelkesedés és az akarat töretlen maradt, a humán töke és a társadalmi tőke erősnek bizonyult, s ezek következtében a különböző pályázatok is sikeresek voltak. Ezt a lelkesedést, tapasztalatot és tudást kell átmenteni a területfejlesztési törvény módosítása utáni állapotra, a többcélú kistérségi társulások múköd- 
tetéséhez, de az erős kistérségi szerveződések jó tapasztalatként és példaként szolgálhatnak a LEADER programok menedzsment szervezeteinek is.

A fenntartható vidékfejlesztési beavatkozásokat alulról közelítve, lokális fejlesztés formájában, a helyi jellegzetességekre koncentrálva kell kidolgozni.

\section{A fenntartható fejlödés stratégiai elemei}

A 21. század fejlesztési stratégiái nem követhetik a 20. század gazdaságnövekedési modelljeit. A szokásos fejlesztési politikákat fel kell váltania a környezet és fejlesztés integrált megközelítésủ stratégiai gondolkodásnak és cselekvésnek. A 20. század növekedési modelljét az energia és a nyersanyag felhasználása jellemezte, mely a természeti eröforrások kiaknázásához vezetett. Ez a modell századunkban nem folytatható, a hosszú távú gondolkodás a fenntarthatóság modelljén alapul.

A „Fenntartható Európa egy jobb világért: az Európai Unió fenntartható fejlődésre vonatkozó stratégiája" hosszútávra pozitív jövóképet határoz meg, melyben Johannesburg óta a három elemet a gazdasági növekedést, a társadalmi kohéziót és a környezet védelmét ötvözi a fenntartható fejlödés érdekében.

A dokumentum meghatározza azokat a tényezöket, veszélyeket, melyek leginkább veszélyeztetik a fenntartható fejlődést, s ezek a kỏvetkezők (EC 2001):

- üvegházhatás, globális felmelegedés,

- hosszútávon a kemikáliák használatának negatív hatásai: veszélyek az élelmiszer biztonságra,

- a szegénység és a társadalmi kirekesztettség, mely együtt jár a munkanélküliséggel,

- a jelenlegi korstruktúra, a születési ráta alacsony volta,

- a biodiverzitás csökkenése, a szemétmennyiség növekedése és a talajszenynyezés, erózió, degradáció,

- közlekedés fokozódásával járó ártalmak, regionális egyenlötlenség.

Közvetett módon valamennyi tényezó hozzájárul a magyarországi vidéki térségek fenntartható fejlődés akadályaihoz, így a vidékfejlesztési (és nem az agrárium) intézkedések szempontjából valamennyi tényezöre koncentrálni kell.

Az Európai Unió Fenntartható Fejlesztési Stratégiájának hosszú távú céljai és prioritásai:

- a tárcák közötti széles egyeztetés a szükséges tettek megtételért,

- a megújuló energiahasznosítás növelése a klímaváltozás visszaszorítása érdekében,

- a közegészségügy veszélyeire való odafigyelés - élelmiszerbiztonság, kemikáliák elóálítása, használata,

- a természeti erőforrásokkal való felelősségteljesebb gazdálkodás,

- a közlekedés és a földhasználat javítása. 
Eszközök a célok eléréséhez:

- növelni a politikai koherenciát,

- piaci megújulások az üzleti szférára a természeti erőforrások fenntartható módon történö hasznosításra,

- a tudományba és a müszaki fejlesztésbe való beruházás a jövő számára,

- javítani a kommunikációt,

- a bővítés és a globális dimenziók figyelembe vétele.

Mind az EU szinten, mind tagországaiban a fenntartható fejlesztési stratégiák a gazdasági, a társadalmi és a környezeti politika összehangolását hangsúlyozzák.

A fenntarthatóság modelljének alkalmazása esetén valóra váló társadalom az ún. alternatív társadalom elnevezést kapta, és legmeghatározóbb tulajdonságai; az ökológiai egyensúly, az alacsony energiafelhasználás, a redukált, vagy zérus szennyezés, a reciklálás, a kézmúves termelés, demokratikus részvételen alapuló politika, helyi kultúrák fejlesztése, szükséglet alapú innováció, decentralizáció, minőség.

A fenntartható vidékfejlesztés célja: a vidéki térségekben élők életkörülményeink és esélyegyenlőségének a javítása, a gazdasági, társadalmi, kömyezeti fenntarthatóság egyensúlyában, amiből következik, hogy a kialakított jövőképnek az életminöség jobbítását kell célul tüznie (3. ábra).

\section{3. ÁBRA}

A fenntartható vidéki fejlödés jövöképe (Vision for Sustainable Rural Development)

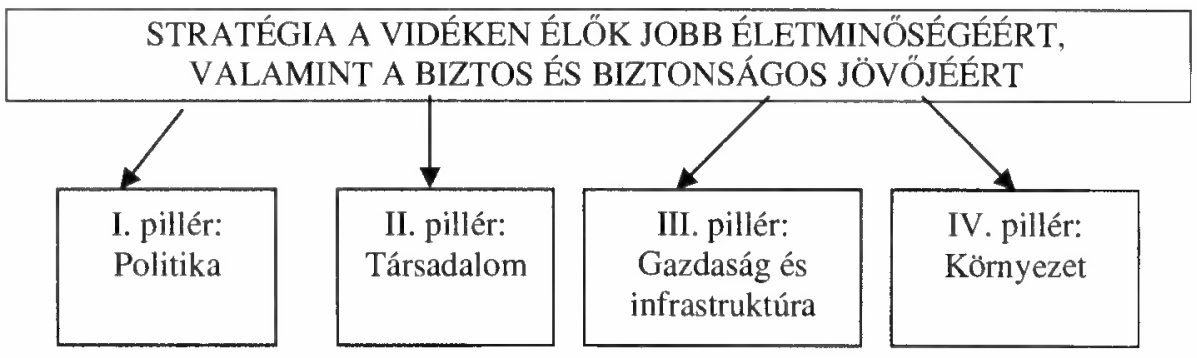

Forrás: Saját szerkesztés.

A nagy kérdés, hogy a meghatározott jövökép elérhetö-e, s hogyan érhetö el? A fenntarthatóság jegyében miért kell a három, illetve négy pillér egyensúlyára törekedni?

A stratégiaépítés hosszútávon csakis a környezetállapotának megóvásán keresztül lehetséges, tehát minden olyan törekvésnek, mely az adott terület, régió, ország lakosságának életminőségét kívánja javítani, egyetlen kiindulási pontja lehet, mégpedig a környezeti állapot megóvására való törekvés, ami áttételesen szolgálja az életminöség javulását is. Ha a környezet állapota, minösége romlik, akkor rövidtávon lehet bizonyos gazdaságnövelö eszközökkel javulást elérni, de hosszútávon már nem. A fenntartható fejlödés hosszú távon biztosítja a foglalkoztatást, amihez egy 
folyton megújuló tudásra van szükség, mert ez a tudás vezet el a gazdasági innovációhoz, a megújuláshoz, az új technológiák, egyre inkább környezetbarát, magas tudásalapú termékek bevezetéséhez. A kutatás, a fejlesztés és ezek eredményeinek a mindennapokba való átültetése képes a biztonságos jövő megteremtésére, ami a lakosság számára a biztonságos élelmiszerellátást, a közszolgáltatások magas színvonalú biztosítását tudja nyújtani.

A stratégiai fókuszok kijelölik azokat a föirányokat, melyek elvezetnek a rurális térségek fenntartható fejlődéséhez, melyek mind a négy pillérhez (társadalmi, gazdasági, környezeti és politikai) kapcsolódnak úgy, hogy a vidéki gazdaság versenyképességére való törekvéssel párosulnak. Társadalmilag és gazdaságilag fenntarthatóvá egy vidéki térség csak a népességmegtartó képesség és a jövedelemtermelés fokozásával, a vidéki terek felértékelödésével és élettérként való elfogadásával válhat. Az ökológiai fenntarthatóság a társadalmi és gazdasági fenntarthatóság záloga, hiszen ahol nincs fenntartható társadalom, valamint múködő és fenntartható gazdaság, ott fenntarthatatlan folyamatok indulhatnak el a környezetet illetően is. Rövid- és középtávon csakis a versenyképes rurális gazdaság szolgálhatja az ökológiai fenntarthatóságot, hiszen maga a környezet védelme feltételezi, hogy minden szektorban a tudásalapú és a környezetbarát technológiák bevezetésére és alkalmazására kerül sor, mely hozzájárul az ökológiai fenntarthatósághoz. Tehát a versenyképesség és a fenntarthatóság egymást erösítö, és nem egymást kizáró fogalmak. Például, ha rurális tereket meg akarjuk örizni ökológiai értelemben (természetvédelmi területek, nemzeti parkok, tájvédelmi körzetek), ahhoz az ökológiai kutatások legújabb eredményeit is be kell építeni a tájfenntartásba, ha piacképes mezögazdasági termelés a cél, akkor ez csakis versenyképes termékekkel lehetséges, ha az infrastruktúrát kell kiépíteni, akkor a legújabb technológiákat kell alkalmazni, a közlekedésfejlesztés esetén a környezetbarát eszközöket és módokat szabad csak követni. Tehát a vidék csakis akkor válik fenntarthatóvá, ha nem a falusi idillt kívánják a városlakók konzerváłni, hanem akkor, ha az adott rurális tér a lakosságának hozzájárulásával és akaratával válik vonzóvá és élhetövé saját maguk számára.

Hosszú távon csakis a környezeti, ökológiai fenntarthatóság tudja biztosítani a gazdasági és társadalmi fenntarthatóságot, hiszen, ha a vidék ökológiai eltartó képessége csökken, akkor a társadalmi és gazdasági fenntarthatóság zsákutcába torkoll.

A fentiek jegyében három scenárió összeállítására került sor, az optimális, a reális és a pesszimista változatokra (3.,4., 5. táblázat). 
Szörényiné Kukorelli Irén : A fenntartható fejlődés stratégiai elemei a rurális térségekben.

Tér és Társadalom 19. évf. 2005/3-4. 111-137. p.

TÉT XIX. évf. 2005 — 3-4

A fenntartható fejlödés ...

129

\section{TÁBLÁZAT}

Jövökép I. - optimista verzió

(Vision I-Optimistic Version)

\begin{tabular}{|c|c|c|c|c|}
\hline & Társadalmi pillér & Gazdasági pillér & Környezeti pillér & Politikai pillér \\
\hline 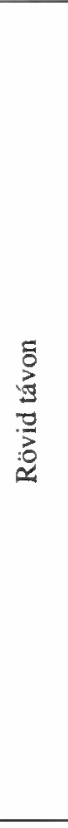 & $\begin{array}{l}\text { A./A tudás alapú } \\
\text { társadalom megte- } \\
\text { remtése vidéken is - } \\
\text { kezdeti lépések } \\
\text { life-long learning } \\
\text { kiterjesztése és } \\
\text { tudás transzfer } \\
\text { infrastruktúra bizto- } \\
\text { sítása (széles sávú } \\
\text { internet minden } \\
\text { vidéki településre) } \\
\text { B./ Közösségen } \\
\text { alapuló integrált } \\
\text { vidékfejlesztés } \\
\text { társadalmi oldalá- } \\
\text { nak erösítése } \\
\text { jóléti szolgáltatási } \\
\text { csomagok kidolgo- } \\
\text { zása (finn tapaszta- } \\
\text { latok) } \\
\text { C./Érdekérvényesí- } \\
\text { teni képes civil } \\
\text { szervezetek eösítése } \\
\text { társadalmi töke } \\
\text { erösítése }\end{array}$ & $\begin{array}{l}\text { A./Közösségen } \\
\text { alapuló integrált } \\
\text { vidékfejlesztés } \\
\text { gazdasági oldalá- } \\
\text { nak erösitése } \\
\text { LEADER progra- } \\
\text { mok elindítása, } \\
\text { fenntartható } \\
\text { rurálturizmus és } \\
\text { ökoturizmus fejlesz- } \\
\text { tése, biotermelés és } \\
\text { értékesítés } \\
\text { B./Munkahely } \\
\text { teremtés }- \\
\text { diverzifikáció } \\
\text { természetes alap- } \\
\text { anyagok és energia- } \\
\text { hordozók termelése } \\
\text { és feldolgozása } \\
\text { C./ Elérhetöség } \\
\text { javítása-fenntart- } \\
\text { ható közlekedési } \\
\text { módokelterjesztése } \\
\text { telepuilésközi utak } \\
\text { kiépítése }\end{array}$ & $\begin{array}{l}\text { A./Erdősités- } \\
\text { támogatások } \\
\text { B./Mesújuló ener- } \\
\text { giák termelésének } \\
\text { preferálása } \\
\text { pl. energiaerdők, } \\
\text { biomassza, } \\
\text { biodiezel, alternatív } \\
\text { energiák beépülése } \\
\text { az energiagazdálko- } \\
\text { dásba } \\
\text { C./NATURA 2000 } \\
\text { programok indítása } \\
\text { újabb nemzeti } \\
\text { parkok kijelölése, } \\
\text { natúr parkok támo- } \\
\text { gatása } \\
\text { D./Agrár- } \\
\text { környezetvédelem } \\
\text { beépülése a helyi } \\
\text { vidékfejlesztésbe }\end{array}$ & $\begin{array}{l}\text { A./ Vidékfejlesztési } \\
\text { Tanács létrehozása } \\
\text { életminöségjavító } \\
\text { intézkedések, kör- } \\
\text { nyezettudatos politi- } \\
\text { ka érvényesítése, a } \\
\text { LEADER programot } \\
\text { nem nyerö helyi } \\
\text { közösségek számára } \\
\text { hasonló hazai prog- } \\
\text { ram indítása } \\
\text { B./A vidékfejlesztés } \\
\text { meghatározó dönté- } \\
\text { si szintie a kistérségi } \\
\text { szint } \\
\text { kistérrégi területfej- } \\
\text { lesztési tanácsok } \\
\text { hatékony müködése, } \\
\text { müködöképes } \\
\text { önkormányzatok } \\
\text { C./ Autonóm kistér } \\
\text { ség - mintaterületek } \\
\text { kijelölése és a } \\
\text { megvalósítás támo- } \\
\text { gatása }\end{array}$ \\
\hline 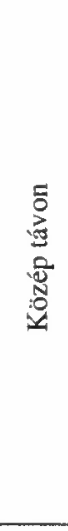 & $\begin{array}{l}\text { D./Közösségen } \\
\text { alapuló integrált } \\
\text { vidékfejlesztés } \\
\text { társadalmi oldalá- } \\
\text { nak erösítése } \\
\text { jóléti szolgáltatási } \\
\text { csomagok bevezeté- } \\
\text { se (finn tapasztala- } \\
\text { tok) } \\
\text { E./Érdekérvényesíte } \\
\text { ni képes civil szer- } \\
\text { vezetek erósítése } \\
\text { civil szféra megha- } \\
\text { tározó szerepének } \\
\text { növelése }\end{array}$ & $\begin{array}{l}\text { E./ Elérhetöség } \\
\text { javitása-fenntart- } \\
\text { ható közlekedési } \\
\text { módok elterjesztése } \\
\text { ökomobilitás, igény- } \\
\text { vezérelt tömegközle- } \\
\text { kedés, alternatív } \\
\text { energia meghajtású } \\
\text { jármüvek } \\
\text { F./Munkahelyte- } \\
\text { remtés - } \\
\text { diverzifikáció } \\
\text { jóléti szolgáltatási } \\
\text { projektek indítása, } \\
\text { hazai helyi fejlesztési } \\
\text { programok indítása }\end{array}$ & $\begin{array}{l}\frac{\text { E./Víz-táj-és }}{\text { körmvezetgazdálko- }} \\
\text { dás } \\
\text { F./Megújuló ener- } \\
\text { giák termelése: } \\
\text { a megújuló ener- } \\
\text { giák arányának } \\
\text { növekedése az } \\
\text { energia struktúrán } \\
\text { belül, } \\
\text { autonóm minta- } \\
\text { kístérségek beveze- } \\
\text { tése }\end{array}$ & $\begin{array}{l}\text { D. Vidékfejlesztési } \\
\text { Tanács müködése } \\
\text { átfogó, következetes } \\
\text { vidékpolitika } \\
\text { E./Magas minöségü } \\
\text { közszolgáltatások } \\
\text { biztosítása azélhe- } \\
\text { több élettérént- } \\
\text { népességmegtartó } \\
\text { intézkedések }\end{array}$ \\
\hline 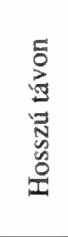 & $\begin{array}{l}\text { C./ Érdekérvényesí- } \\
\text { teni képes civil } \\
\text { szervezetek erösítése } \\
\text { hálózatokkal átszött } \\
\text { tér megvalósítása }\end{array}$ & $\begin{array}{l}\text { G./Közösségen } \\
\text { alapuló integrált } \\
\text { vidékfejlesztés } \\
\text { gazdaságioldala- } \\
\text { nak erösitése } \\
\text { erós, diverzifikált } \\
\text { helyi gazdaság }\end{array}$ & 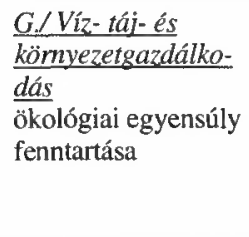 & $\begin{array}{l}\text { F.Nidékpolitika a } \\
\text { fenntartható vidéki } \\
\text { fejlôdésért } \\
\text { életminőség megör- } \\
\text { zése }\end{array}$ \\
\hline
\end{tabular}

Forrás: Saját szerkesztés. 
Szörényiné Kukorelli Irén : A fenntartható fejlödés stratégiai elemei a rurális térségekben. Tér és Társadalom 19. évf. 2005/3-4. 111-137. p.

\begin{tabular}{|c|c|c|c|c|}
\hline \multicolumn{5}{|c|}{$\begin{array}{c}\text { 4. TÁBLÁZAT } \\
\text { Jövókép II. - valószínüsíthetö verzió } \\
\text { (Vision II-Realistic Version) }\end{array}$} \\
\hline & Társadalmi pillér & Gazdasági pillér & Környezeti pillér & Politikai pillér \\
\hline 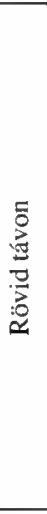 & $\begin{array}{l}\text { A./A tudás alapú } \\
\text { társadalom megteremté- } \\
\text { se vidéken is - kezdeti } \\
\text { lépések } \\
\text { igények gerjesztése } \\
\text { B./ Közöosségen alapuló } \\
\text { integrált vidékfejlesztés } \\
\text { társadalmi oldalának } \\
\text { érösttése } \\
\text { közösségfejlesztés, } \\
\text { helyi rurális társadalom } \\
\text { erösítése }\end{array}$ & $\begin{array}{l}\text { A./ Közösségen alapuló } \\
\text { integrált vidékfejlesztés } \\
\text { gazdaságioldalának } \\
\text { erösítése } \\
\text { LEADER és hasonló } \\
\text { típusú hazai programok } \\
\text { elindítása, fenntartható } \\
\text { rurálturizmus és öko- } \\
\text { turizmus fejlesztése, } \\
\text { biotermelés és értékesítés } \\
\text { B./ Elérhetöség javitá- } \\
\text { sa-fenntartható } \\
\text { közlekedési módok } \\
\text { elterjesztése } \\
\text { falugondnoki buszhá- } \\
\text { lózat kiterjesztése, } \\
\text { iskolajárattal bỏvítése }\end{array}$ & $\begin{array}{l}\text { A./ Erdósités }- \\
\frac{\text { támogatások }}{\text { B./Megújuló energi- }} \\
\text { ák termelése } \\
\text { pl. energiaerdők, } \\
\text { biomassza, } \\
\text { biodiezel, } \\
\text { alternatív energiák } \\
\text { beépülése az } \\
\text { energiagazdálko- } \\
\text { dásba } \\
\text { C./NATURA } 2000 \\
\text { programok indítása }\end{array}$ & $\begin{array}{l}\text { A./Vidékfejlesztési } \\
\text { Tanács létrehozása } \\
\text { életminöségjavító } \\
\text { intézkedések, környezet- } \\
\text { tudatos politika érvé- } \\
\text { nyesítése, a LEADER } \\
\text { programot nem nyerő } \\
\text { helyi közösségek } \\
\text { számára hasonló hazai } \\
\text { program indítása } \\
\text { B./ A vidékfejlesztés } \\
\text { meghatározó döntési } \\
\text { szintje a kistérségi szint } \\
\text { kistérségi területfejlesz- } \\
\text { tési tanácsok hatékony } \\
\text { müködése, müködöké- } \\
\text { pes önkormányzatok }\end{array}$ \\
\hline 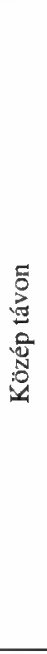 & $\begin{array}{l}\text { C./A tudás alapú } \\
\text { társadalom megterem- } \\
\text { tése vidéken is } \\
\text { life-long learning } \\
\text { kiterjesztése és tudás } \\
\text { transzfer in frastruktúra } \\
\text { biztosítása (széles sávú } \\
\text { internet minden vidéki } \\
\text { településre) } \\
\text { D./Közösségen alapuló } \\
\text { integrált vidékfejlesztés } \\
\text { társadalmi oldalának } \\
\text { erósítése } \\
\text { jóléti szolgáltatási } \\
\text { csomagok kidolgozása } \\
\text { (finn tapasztalatok) }\end{array}$ & $\begin{array}{l}\text { C./ Közösségen alapu- } \\
\text { ló integrält vidékfej- } \\
\text { lesztés gazdasági } \\
\text { oldalának erósítése } \\
\text { LEADER és a hazai } \\
\text { helyi fejlesztési prog- } \\
\text { ramok le fedik a hazai } \\
\text { rurális térségeket } \\
\text { D./Munkahelvteremtés } \\
\text {-diverzifikáció } \\
\text { Természetes alapanya- } \\
\text { gok és energiahordozók } \\
\text { termelése, feldolgozása } \\
\text { és értékesítése } \\
\text { E./Elérhetöség javítá- } \\
\text { sa-fenntartható } \\
\text { közlekedési módok } \\
\text { elterjesztése } \\
\text { falusi térségek elérhe- } \\
\text { tőségének javítása, } \\
\text { településközi utak } \\
\text { kiépítése }\end{array}$ & $\begin{array}{l}\frac{D . / \text { Viz-táj-és }}{\text { környezetgazdálko- }} \\
\frac{\text { dás }}{\text { E./Megújuló }} \\
\frac{\text { energiák termelése: }}{\text { autonóm kistérségi }} \\
\text { minta bevezetése } \\
\text { F/NATURA } 2000 \\
\text { programok mükö- } \\
\frac{\text { dése }}{\text { újabb nemzeti }} \\
\text { parkok kijelölése, } \\
\text { natúr parkok } \\
\text { támogatása }\end{array}$ & $\begin{array}{l}\text { C./ Autonóm kistérség - } \\
\text { mintaterïletek kijelölése } \\
\text { és a megvalósitásának } \\
\text { támogatása } \\
\text { D./ Vidékfejlesztési } \\
\text { Tanács müködése } \\
\text { átfogó, következetes } \\
\text { vidékpolitika }\end{array}$ \\
\hline 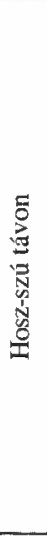 & $\begin{array}{l}\text { E./Érdekérvényesíteni } \\
\text { képes civil szervezetek } \\
\text { erösítése } \\
\text { civil szféra meghatáro- } \\
\text { zó szerepének növelése } \\
\text { F./ Közösségen alapuló } \\
\text { integrált vidékfejlesztés } \\
\text { társadalmi oldalának } \\
\text { erösítése } \\
\text { jóléti szolgáltatási } \\
\text { csomagok bevezetése } \\
\text { (finn tapasztalatok) } \\
\text { G./Érdekérvényesíteni } \\
\text { képes civil szervezetek } \\
\text { erösitése } \\
\text { hálózatokkal átszött tér } \\
\text { megvalósítása }\end{array}$ & $\begin{array}{l}\text { F./Elérhetöség javítá- } \\
\text { sa-fenntartható } \\
\text { közlekedési módok } \\
\text { elterjesztése } \\
\text { ökomobilitás, igény- } \\
\text { vezérelt tömegközle- } \\
\text { kedés, alternatív ener- } \\
\text { gia meghajtású jármüvek } \\
\text { G./Munkahelyteremtés } \\
\text {-diverzifikáción } \\
\text { jóléti szolgáltatási } \\
\text { projektek indítása } \\
\text { H./Közösségen alapuló } \\
\text { integrált vidékfejlesztés } \\
\text { gazdasági oldalának } \\
\text { erösitése } \\
\text { erös helyi rurális } \\
\text { gazdaság }\end{array}$ & $\begin{array}{l}\text { G./Megújuló } \\
\text { energiák termelése } \\
\text { a megújuló ener- } \\
\text { giák arányának } \\
\text { növekedése az. } \\
\text { energia struktúrán } \\
\text { belül, } \\
\text { autonóm minta- } \\
\text { kistérségek beveze- } \\
\text { tése } \\
\text { H./Viz- táj-és } \\
\text { körnvezetgazdalko- } \\
\text { dás } \\
\text { ökológiai egyensúly } \\
\text { fenntartása }\end{array}$ & $\begin{array}{l}\text { E./Magas minỏségü } \\
\text { közszolgáltatások } \\
\text { biztosítása azélhetöbb } \\
\text { élettérért- } \\
\text { népességmegtartó } \\
\text { intézkedések } \\
\text { F. Vidékpolitika a fenn- } \\
\text { tantható vidéki fejlödésért } \\
\text { életminőség megórzése }\end{array}$ \\
\hline
\end{tabular}

Forrás: Saját szerkesztés. 
Szörényiné Kukorelli Irén : A fenntartható fejlödés stratégiai elemei a rurális térségekben. Tér és Társadalom 19. évf. 2005/3-4. 111-137. p.

TÉT XIX. évf. 2005 -3-4

A fenntartható fejlödés...

131

\begin{tabular}{|c|c|c|c|c|}
\hline \multicolumn{5}{|c|}{$\begin{array}{c}\text { 5. TÁBLÁZAT } \\
\text { Jövökép III. - Pesszimista verzió } \\
\text { (Vision III-Pessimistic Version) }\end{array}$} \\
\hline & Társadalmi pillér & Gazdasági pillér & Környezeti pillér & Politikai pillér \\
\hline 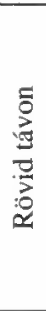 & $\begin{array}{l}\text { A./A tudás alapú } \\
\text { társadalom megte- } \\
\text { remtése vidéken is } \\
\text { - kezdeti lépések } \\
\text { igények gerjesztése }\end{array}$ & $\begin{array}{l}\text { A./ Közösségen alapu- } \\
\text { ló integrált vidékfej- } \\
\text { lesztés gazdasági } \\
\text { oldalának erösítése } \\
\text { LEADER programok } \\
\text { elindítása }\end{array}$ & $\begin{array}{l}\frac{\text { A./Erdösttés - }}{\text { támogatások }} \\
\text { B./NATURA } 2000 \\
\text { programok indítása }\end{array}$ & $\begin{array}{l}\text { A./ A vidékfejlesztés } \\
\text { meghatározó döntési } \\
\text { szintie a kistérségi } \\
\text { szint } \\
\text { nemérvényesül a } \\
\text { bottom-up politika, a } \\
\text { kistérségi szint csupán } \\
\text { a központi kormányzat } \\
\text { „meghosszabbított } \\
\text { csápja" }\end{array}$ \\
\hline 离 & $\begin{array}{l}\text { B./A tudás alapú } \\
\text { társadalom megte- } \\
\text { remtése vidéken is } \\
\text { life-long learning } \\
\text { kiterjesztése, } \\
\text { távoktatási techni- } \\
\text { kák infrastruktúrá- } \\
\text { jának megteremtése } \\
\text { C./ Közösségen } \\
\text { alapuló integrált } \\
\text { vidékfejlesztés } \\
\text { társadalmi oldalá- } \\
\text { nak erösítése } \\
\text { közösségfejlesztés, } \\
\text { helyi rurális társa- } \\
\text { dalom erösítése }\end{array}$ & $\begin{array}{l}\text { B./ Közösségen alapu- } \\
\text { ló integrált vidékfej- } \\
\text { lesztés gazdasági } \\
\text { oldalának erösitése } \\
\text { LEADER programok } \\
\text { megvalósítása néhány } \\
\text { helyen, fenntartható } \\
\text { rurálturizmus és } \\
\text { ökoturizmus fejleszté- } \\
\text { se, biotermelés és } \\
\text { értékesítés } \\
\text { C./ Elérhetöség javí- } \\
\text { tása-iskolabusz } \\
\text { hálózat, falugondnoki } \\
\text { hálózat } \\
\text { D./Munkahelyterem- } \\
\text { tés-diverzifikáció } \\
\text { Természetes alap- } \\
\text { anyagok és energia- } \\
\text { hordozók termelése és } \\
\text { feldolgozása }\end{array}$ & $\begin{array}{l}\frac{C . / V i ́ z-t a ́ j-e ́ s}{\text { körnvezetgazdál- }} \\
\text { kodás } \\
\text { D./Megújuló } \\
\text { energiák termelése } \\
\text { pl. energiaerdök, } \\
\text { biomassza, } \\
\text { biodiezel, } \\
\text { alternatív energiák } \\
\text { beépülése az } \\
\text { energiagazdálko- } \\
\text { dásba }\end{array}$ & $\begin{array}{l}\text { B./Vidékfejlesztési } \\
\text { Tanács létrehozása } \\
\text { elódázhatatlan a } \\
\text { Tanács létrehozása: } \\
\text { életminöségjavító } \\
\text { intézkedések, kör- } \\
\text { nyezettudatos politika } \\
\text { érvényesítése, a } \\
\text { LEADER programot } \\
\text { nem nyerö helyi } \\
\text { közösségek számára } \\
\text { hasonló hazai prog- } \\
\text { ram indítása } \\
\text { C./A vidékfejlesztés } \\
\text { meghatározó döntési } \\
\text { szintje a kistérségi } \\
\text { szint, marad az } \\
\text { elaprózott önkor- } \\
\text { mányzati rendszer }\end{array}$ \\
\hline 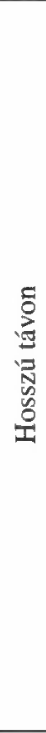 & $\begin{array}{l}\text { D./A tudás alapú } \\
\text { társadalom megte- } \\
\text { remtése vidéken is } \\
\text { life-long learning } \\
\text { kiterjesztése és tudás } \\
\text { transzfer, } \\
\text { infrastruktúra bizto- } \\
\text { sítása (széles sávú } \\
\text { intemet minden } \\
\text { vidéki településre) } \\
\text { E./ Közzösségen } \\
\text { alapuló integrált } \\
\text { vidékfejlesztés } \\
\text { társadalmi oldalá- } \\
\text { nak erösitése } \\
\text { jóléti szolgálttásisi } \\
\text { csomagok kidolgozá- } \\
\text { sa (finn tapasztalatok) } \\
\text { F./Érdekérvényesí- } \\
\text { teni képes civil } \\
\text { szervezetek erösítése } \\
\text { civil szféra megha- } \\
\text { tározó szerepének } \\
\text { növelése }\end{array}$ & $\begin{array}{l}\text { E./ Közösségen alapu- } \\
\text { ló integrált vidékfej- } \\
\text { lesztés gazdasági } \\
\text { oldalának erösítése } \\
\text { LEADER múködése } \\
\text { és a hazai helyi fej- } \\
\text { lesztési programok } \\
\text { indítása } \\
\text { F./ Elérhetốség javitá- } \\
\text { sa-fenntartható } \\
\text { közlekedési módok } \\
\text { elterjesztése } \\
\text { falugondnoki buszhá- } \\
\text { lózat kiterjesztése és } \\
\text { iskolajárattal bövítése, } \\
\text { településközi utak } \\
\text { kiépítése } \\
\text { G/ Munkahelyterem- } \\
\text { tés - diverzifikáció } \\
\text { jóléti szolgáltatásís } \\
\text { projektek indítása }\end{array}$ & $\begin{array}{l}\text { E./Megújuló } \\
\text { energiák termelése } \\
\text { autonóm kistérségi } \\
\text { minta bevezetése, } \\
\text { autonóm kistérsé- } \\
\text { gek kijelölése } \\
\text { F./Megújuló } \\
\text { energiák termelése } \\
\text { arányuk növekedni } \\
\text { kezd az energia- } \\
\text { struktúrában } \\
\text { G./NATURA 2000 } \\
\text { programok mükö- } \\
\text { dése } \\
\text { újabb nemzeti } \\
\text { parkok kijelölése, } \\
\text { natúr parkok } \\
\text { támogatása } \\
\text { H./Víz-táj-és } \\
\text { környezetgazdál- } \\
\text { kodás } \\
\text { ökológiai egyensú- } \\
\text { lyért folytatott harc }\end{array}$ & 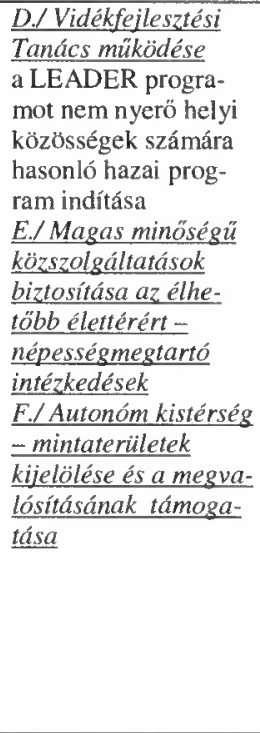 \\
\hline
\end{tabular}

Forrás: Saját szerkesztés. 


\section{A megvalósíthatóság a négy pillér jegyében}

\section{I. pillér: Politikai döntések a fenntartható vidékfejlesztésért}

A vidék társadalmi, gazdasági és ökológiai fenntarthatósága nagymértékben függ a nemzeti, a regionális és a helyi a politikai döntésektől. Ma Magyarországon valójában nincs gazdája a vidékfejlesztésnek. 2003-ig az FVM-en belül müködött egy Vidékfejlesztési Föosztály, létrejöttek a regionális Vidékfejlesztési Irodák (REVI), és a vidékfejlesztési kistérségi szinten egy-egy menedzser látta el a szélesen értelmezett vidékfejlesztési feladatokat. Ez a rendszer 2003-ban megszünt. Az FVM-en belül ma létezik az Agrár-, Vidékfejlesztési és Környezetgazdálkodási Főosztály, de mint a neve is mutatja, ennek elsődleges feladata az agrár-környezetvédelem ellátása. A SAPARD program befejezésével megszünt 2003-ban a SAPARD Hivatal, és jogutódaként az Agrárintervenciós Központtal együtt létrejött a Mezögazdasági és Vidékfejlesztési Hivatal. Feladata a kifizető ügynökségi feladatok, valamint a támogatási rendszer müködtetése, és az ehhez szükséges ellenőrzési feladatok ellátása. Ezek a szervezetek nem tudják kezelni a vidéki népesség szociális, foglalkoztatási, települési, területfejlesztési feladatait és a gazdaság megújítási igényeit (Magyarország SAPARD ... 2002; Nemzeti Vidékfejlesztési Terv 2004). Ha összevetjük a fenntartható vidékfejlesztés fogalmát és a vidékfejlesztés stratégiai célját, valamint a sokszor elismételt megállapításokat, miszerint a vidékfejlesztés nem mezőgazdasági fejlesztés, a vidéken élők kis hányada foglalkozik csak mezögazdasággal, és cél a vidéken élök életminőségének a javítása, akkor az alábbi négy pontban foglalható össze a fenntartható vidéki fejlődés politikai aspektusa:

\section{Nemzeti Vidékpolitikai Tanács létrehozása}

Egyetértve a „Párbeszéd a vidékért” program javaslataival, szükség van a 2006-2013 között egy olyan szervezet létrehozására, mely érzékeny a vidék minden irányú problémáira, szem elótt tartja a vidék érdekeit, érvényesíti a hazai vidékpolitikában a fenntarthatóság elveit, és folytonos párbeszédet folytat, s ha kell, közvetít a vídék különbözö - nem csak a mezỏgazdaságot érintő - szereplői között (Glatz 2005).

\section{A fenntartható vidéki fejlödés intézményrendszerének kialakítása}

Olyan intézményrendszerre van szükség, mely átlátható, stabil és befogadója tud lenni az alulról jövő kezdeményezéseknek. A vidékfejlesztés nem agráriumot érintő fejlesztési tevékenységeit át kell irányítani a terulet- és regionális fejlesztésért felelỏs tárcához, úgy, hogy mind regionális, mind kistérségi szinten egy fejlesztési szervezet legyen felelős a kitüzött célok és feladatok megvalósításáért (Rechnitzer 2003). Szükség van az új intézményrendszerre azért is, hogy segítse az Új Nemzeti Vidékfejlesztési Terv (NVT II) és új Agrár- és Vidékfejlesztési Operatív Program 2 (AVOP 2) készítését a 2007-2013 közötti időszakra, és épüljön bele a fenntartható vidéki fejlődés stratégiája. A kialakított intézményrendszer és hozzá kapcsolódó eszközrendszer fel tudja vállalni a differenciált rurális térségek differenciált kezelését. Forrást teremt a LEADER-hez hasonló hazai program elindítására, és kezeli annak megvalósítását. 


\section{Decentralizáció a vidékfejlesztésben}

A fenntartható vidéki fejlỏdés csak a decentralizáció és a bottom-up politika érvényesítésével érhetö el, ezért erősödjenek meg a Kistérségi Területfejlesztési Tanácsok, s munkaszervezetükben kapjanak helyet a vidékfejlesztési szakemberek.

A decentralizáció érvényesítésére a LEADER programhoz hasonló hazai vidékfejlesztési program megteremtése segítené a fejlődésben azokat a rurális térségeket, közösségeket, melyek a LEADER program által nem kedvezményezett térségek, és megvalósíthatnának a LEADER-hez hasonló fejlesztéseket, mint Finnországban müködő POMO vagy ALMA programok, melyek a LEADER mellett müködnek (Usitalo 1999).

\section{Az érdekérvényesités erösitése}

A decentralizáció csak erős helyi civil szervezetek müködésével valósítható meg, ezért törekedni kell a közösségépítésen keresztül a helyi társadalmi töke megerösítésére. A társadalmi tőke segítségével az érdekérvényesítő képesség nő, mely hozzájárul a lokális fejlesztési minták elterjedéséhez és eredményességéhez. Ezért kapjanak állami támogatást a rurális érdekérvényesítỏ szervezetek. A vidék civil szervezeteinek politikai, szakmai, módszertani, információs megerősítése, valamint térségi és regionális hálózatok, szakmai szolgáltató-bázisok kialakítása elvezet a hálózatokkal átszőtt térhez, melyben a rurális tér feloldódik, s a tágabb világ már nem kívülröl hat a helyi közösségekre, hanem saját belső folyamatai szerves részévé válnak a kitágult világnak (Mardsen 1999).

Il. pillér: A tudáshiány felszámolása és az esélyegyenlöség biztositása a fenntartható vidéki társadalomért

Ma Magyarország vidéki térségeinek társadalmi összetétele nagyon különbözö, de egyben azonos. A vidéki térségek tudáshiányban szenvednek, a humáneröforrás vesztése a fenntarthatóságot veszélyezteti. Fenntartható vidéki társadalom versenyképes gazdaságot és környezetgondos tudatot feltételez, de ehhez a vidéki lakosság tudásbázisa ma nem elég, ez csak tanulással, képzéssel érhető el. Másrészt, hogy a vidéki térségek vonzó lakhelyül szolgáljanak, biztosítani kell az ott élők esélyegyenlöségét a közjavak eléréséhez.

\section{Tudás alapú társadalom megteremtése vidéken is}

A rurális térségeket sújtó társadalmi kirekesztettség oka elsősorban a tudáshiány. Ma a társadalmi kirekesztettség elleni küzdelem eszköze az oktatás. Az iskolarendszerủ oktatáson kívül a nem iskolarendszerủ oktatást és képzést is kínálni kell minden olyan szektor területén, mely érinti a rurális gazdaságot, azzal, hogy az egészéleten-át-tartó tanulás terjedjen ki az egész rurális társadalom valamennyi rétegére. A nonformális és informális képzési formák elfogadottságát növelni kell az egész társadalom és a munkaadók körében is. 
2. Környezettudatos tanulási folyamat a fenntartható fejlödés megvalósításáért

A fenntartható fejlödés fogalmát és a hozzá vezető utat a társadalom valamennyi tagjának meg kell ismerni, máskülönben a jövőkép megvalósítása ellehetetlenül. A lokális és globális környezeti veszélyek, az egészséges életmód, az egészséges táplálkozás megismerése és elsajátítása a társadalom fenntarthatóságát szolgálja.

A 21. században a fenntarthatóság másik kritériuma hálózatok részévé válni, de ehhez a vidéki társadalomnak nyitottabbnak, befogadóbbnak és kapcsolatépítőnek kell lenni, amelyet csak speciális, erre fókuszáló tanulási folyamattal lehet csak elérni (Rhisiart-Thomas 2004).

\section{Magas minöségü közszolgáltatások a népességmegtartás képességéért vidéken}

A vidéki térségekben élők esélyegyenlöségének megteremtése érdekében a szociális ellátást és az egészségvédelmet fokozni szükséges, ösztönzö programokat kell kidolgozni a vidéken letelepuulni és dolgozni akaró fiatal értelmiség számára, különösen azon foglalkoztatási ágakban, melyek tudást közvetítik, a közszolgáltatást végzik, egészségvédelmét növelik, illetve a szociális ellátást biztosítják.

\section{III. pillér: Versenyképes gazdaság a fenntartható vidékért}

A fenntartható vidéki gazdaság jövedelemtermelő rurális teret tételez fel. A rurális tér társadalmi, gazdasági és környezeti jellemzői meghatározzák a gazdaság arculatát. A versenyképes rurális gazdaság sokarcú, diverzifikált, s nem csak a termelö ágazatokra, hanem a szolgáltatások széles körére is fókuszál. A rurális térségekben különösen a kisvárosokban, a térség- és gazdaságszervezö központokban szükséges a szolgáltatás kibővítése, mely a munkahely-teremtést, a foglalkoztatást növelni tudja, miközben szolgálja a jövőképben meghatározott ,életminöség javítás”-t a fenntartható gazdaság által. A versenyképes multifunkcionális mezógazdaság mellett a versenyképes ipari kisés középvállalkozások a rurális terek éltetői. A leghátrányosabb helyzetú rurális terekben a szociális gazdaság segíthet a foglalkoztatottság szintjének emelésén, amelynek a gazdaságba történő helyes integrálása a vidék fenntarthatóságát növelni képes.

1. A közösségen alapuló integrált vidékfejlesztés - LEADER és a LEADER típusú fejlesztések kistérségi szinten

A LEADER típusú helyi fejlesztési modell az EU sikeres vidékfejlesztési modellje. A közvetlen gazdasági fejlesztésen és a foglalkoztatás növelésén túl az innovatív tevékenységet ötvözi a rurális értékek megórzésével, széles kapcsolatépítésen keresztül, mely gerjesztője az újabb és újabb rurális innovációnak. A LEADER típusú fejlesztések színtere a kistérségi szint. De nem feltétlenül a mai kistérségi besorolás alapján, hanem minden olyan helyi közösség kezdeményezö lehet, mely a helyi érdekre és akaratra épít, messzemenően figyelembe véve a helyi természeti, kulturális adottságokat. A LEADER vagy azzal megegyező típusú, de hazai fejlesztési forma minden olyan térségben eredményes lehet, ahol a minőséget és az egyediséget helyezik az első helyre. 


\section{Mezögazdaság multifunkcionális szerepe - diverzifikált jövedelemtermelés}

A mezögazdaságnak, mint ágazatnak megváltozott a szerepe. Már elsödlegesen nem az élelmiszer mennyiségi termelése, hanem minőségi élelmiszer előállítása a feladata. A másik, s egyre jelentősebb funkciója az élelmiszer termelés mellett az energia növények termelése. A harmadik funkció a környezetgazdálkodás, tájgondozás és fenntartás. A természeti és kulturális diverzitás értékének megismeréséhez pedig a rurálturizmus járulhat hozzá, mely a diverzifikációt tovább szélesíti a gazdaság egészében.

\section{Tudásalapú technológiák elterjesztése a vidék gazdaságában}

A rurális gazdaság csak akkor lesz a nemzetgazdaság integráns része, ha az adottságait kihasználva, s rájuk alapozva a gazdaság valamennyi szektorában a tudásalapú technológiákat alkalmazza. A mezögazdaság, mint a vidék multifunkcionális ágazata, valamennyi ágában a legújabb kutatási eredmények alkalmazásával a környezeti fenntarthatóságot kell, hogy megcélozza. Az energia növények termelése, valamint a tájfenntartó képesség és tevékenység is a fentiekhez járul hozzá. Az erdőknek, az erdészetnek kiemelkedő szerepe lesz a megújítható alapanyag hasznosítása területén, s feldolgozásuk tudásalapú technológiát igényel. De ugyanígy tudásalapú technológiák bevezetését igénylik a rurális térben gyökeret vert ipari jellegủ kis- és középvállalkozások is. A szolgáltatások csak akkor lesznek képesek a megmaradásra, ha azok ugyanazt, ugyanazon a szinten képesek nyújtani, mint urbánus „társaik”.

IV. pillér: Környezetgondos politika és tevékenység a fenntartható környezetért a rurális térben

A környezetgondos politika térhódításával a vidék gazdaságának nemcsak a környezeti fenntarthatóságát, hanem a társadalmi és gazdasági fenntarthatóságát is hosszú távon meg lehet alapozni. Olyan régi-új munkahelyeket lehet teremteni, ún. környezet karbantartó munkahelyeket, melyek a táj fenntartó-képességét növelik, és hozzájárulnak a jövőkép megvalósításához, azaz az életminőség javításához mind a városi, mind a rurális népesség számára.

1. Minta értékü ,,autonóm kistérségek" - önfenntartó kistérségek megvalósításának támogatása-mintaprojektek inditása és terjesztése

Akár a LEADER, vagy ahhoz hasonló nemzeti finanszírozású program keretében önfenntartó rurális kistérségek fejlesztési programjainak indítása, illetve már elindított helyi fenntartási programok további finanszírozása. Kerüljenek bevezetésre környezetbarát technológiák (vegyszermentes növénytermesztés, biogazdálkodás), alternativ energia felhasználás (pl. biomassza erőmü és alapanyagának megtermelése), ökoturizmus kialakítása, valamint a turizmushoz és a közlekedéshez kapcsolódóan az ökomobilitás mintáinak megvalósitása.

\section{Megújuló energiák termelése és felhasználása a vidéki gazdaságban}

A rurális gazdaságot belátható időn belül âtformálja a megújuló energiák termelése, a biomassza alapanyagok gyártása, de csak akkor teljesül a fenntarthatóság 
kritériuma, ha nemcsak kiszolgálója, hanem felhasználója is lesz ezeknek az alapanyagoknak. Az innovatív jellegü anyagok, technológiák kerüljenek helyben, a rurális térben kipróbálásra, mert ezzel növelni lehet az adott térség innovativitását és versenypozícioját.

3. Víz-, táj-és környezetgazdálkodás a fenntarthatóság elvei alapján

Az egész rurális teret át kell hogy szöje a fenntartható környezetgazdálkodás, de fokozottan törekedni kell arra, hogy a NATURA 2000 területek váljanak mintatérségekké. A vidék közhasznát azzal lehet megőrizni, ha a kultúrája és környezete megőrzi diverzitását, és saját maga lesz gazdája környezetének. A nemzeti parkok és pufferzónájuk, valamint a natúrparkok zászlóvivői lesznek a fenntarthatóság mindhárom pillérének.

A fenntartható fejlỏdésnek két egymástól jól elkülöníthető modelltípusa van, attól függỏen, hogy az emberközpontúságot vagy az ökológiai súlypontot hangsúlyozza. A fenti anyag a fenntartható vidéki fejlödés emberközpontú megközelítését helyezi a központba, sôt, mivel a stratégia egy ország vidéki térségeire koncentrál, ezért a globális elemekből csak azokra fókuszál, melyek a lokális elemekkel kapcsolatban vannak. Fontos lenne, ha már elkészült az ország fenntartható fejlődési stratégiája, a lépésenkénti megvalósításának hatását mérni, amihez interdiszciplináris megközelítésre, szakértő gárdára, kutatásra, hatásvizsgálatokra lenne szükség. Az amerikai Yale egyetem nevéhez füzödő, ún. környezeti fenntarthatósági index lehetőséget ad az országok közötti fenntarthatósági mérték összehasonlítására (Simai 2001), de a hazai fenntartható vidéki fejlődési stratégia megvalósításának hatásvizsgálatára egy új, a hazai vidéki fejlödésre vonatkozó adaptív mutatószám rendszerre van szuikség, amely felhasználásával kidolgozásra kerülne a vidék fenntarthatósági indexének meghatározása a politikai a társadalmi, a gazdasági és a környezeti pillérre vonatkozóan.

\section{Jegyzetek}

${ }^{1}$ Földhasználat Magyarországon a 2000. évben KSH Budapest, 2000.

${ }^{2}$ Budapestet nem tekintjük kistérségnek, adataival nem számolunk, mert az jelentős torzítást eredményezne.

\section{Irodalom}

Bognár M.-Imre A.-Mezei I. (2001) Az oktatás és a képzés helye a területfejlesztésben. Mintaterület: az Ozd-putnoki kistérség. - Tér és Társadalom. 15. 3-4, 105-124. o.

Csatári B. (2004) Magyarország új vidékfejlesztési tézisei. - MTA RKK ATI, Kecskemét.

EC (2001) A Sustainable Europe for a Better World. A European Union Strategy for Sustainable Development. - Commission's Proposal to the Gothenburg European Council. COM, Brussels. 264. o.

Glatz F. (2005) A vidéki Magyarország jövoóje, (kézirat) - „Párbeszéd a vidékért” mozgalom.

Ilbery, B. (1998) The Geography in Rural Change. Longman, Essex.

Illés I. (1993) Város- és falufejlesztés dichotómiája a magyar telepuiléshálózat fejlesztésében. -Kovács K. (szerk.). Település, gazdaság, igazgatás a térben. MTA RKK, Pécs. 35-48. o.

Kearney, B.-Boyle, G.E.-Walsh, J.A. (1994) EU LEADER Initiative in Ireland: Evaluation and Recommendations. Dublin, Department of Agriculture, Agriculture House.

Kiss J. (2002) A magyar mezógazdaság világgazdasági mozgástere. Akadémiai Kiadó, Budapest.

Kovács T. (2003) Vidékfejlesztési politika. Dialóg Campus, Budapest-Pécs. 
Közös Jövönk - A Környezet és Fejlesztés Világbizottság Jelentése. (1988) - Persányi M. (szerk.). Mezỏgazdasági Kiadó, Budapest.

Láng I. (2002) Környezetvédelem - fenntartható fejlödés. - Mindentudás Egyeteme. (http://www.mindentudas.hu/lang/20040806langl.html)

Lehota Á. (2003) A falusi lakosság foglalkoztatási problémái. - A vidéki Magyarország az EU csatlakozás elött VI. Falukonferencia. - Kovács 'T. (szerk.) MTA RKK-MRTT, Pécs. 328-333. o.

Magyarország SAPARD terve 2000-2006. (2002) Földmüvelésügyi és Vidékfejlesztési Minisztérium, Budapest. http://www.fvm.hu/doc/upload/200503/sapard_terv.pdf.

Mardsen, T. (1999) Economic Perspective - The Geography of rural change. Ilbery, B. (ed.) Longman, UK. 13-31. o.

Meirion, T.-Martin, R.A. (eds.) (2004) Sustainable Regions making sustainable development work in regional economies. Aureus Publishing, Wales.

Momsen-Kukorelli Szörényiné (2005) Gender and Rural Tourism in Western Hungary-XXI ESRS Congress, Keszthely.

Moseley, J.M. (2003) Rural Development Principle and Practices. Sage Publication, London.

Murdoch, J.-Lowe, P.-Ward, N.-Marsden, T. (2003) The Differentiated Countryside. Routledge Studies in Human Geography Routledge, London - New York.

Nemzeti Vidékfejlesztési Terv (2004) Földmüvelésügyi és Vidékfejlesztési Minisztérium, Budapest. http://www.fvm.hu/doc/upload/200409/nvt1.pdf.

OECD (1990) Rural Development Policy. Organisation for Economic Co-operation and Development, Paris.

Planting Seeds for Rural Futures. Rural Policy Perspectives for a Wider Europe. (2003) - Second European Conference on Rural Development Salzburg Conference Centre, Salzburg. http://europa.eu.int/ comm/agriculture/events/salzburg/proceedings_en.pdf

Rechnitzer J. (2005) Intézményrendszer, finanszírozás. 1. munkacsoport vitaanyaga. (kézirat) - Párbeszéd a vidékért mozgalom munkacsoportjainak vitaanyaga.

Simai M. (2001) Zöldebb lesz-e a világ? A fenntartható fejlödés szerkezeti problémái a XXI. század elején. Akadémiai Kiadó, Budapest.

The Fifth EC Environmental Action Programme. (1992) -Official Journal of the European Communities. (1993), 138/5. European Commission, Brussels. http:/europa.eu.int/comm/environment/envact5/5eap.pdf

Usitalo, E. (1999) The Basics of Finnish Rural policy vitality for rural areas. Why, for Whom and How? Helsinki, Sisaasiainministeriön Monistamo.

\section{ELEMENTS OF SUSTAINABLE RURAL DEVELOPMENT STRATEGY IRÉN SZÖRÉNYINÉ KUKORELLI}

The implementation of sustainable development is not only the task of a country or a region but it is the responsibility of everyone regardless of their geographic position. Since 2001, the Strategy for Sustainable Development has existed in the European Union. In connection with this strategy every EU member state has to develop and implement their own sustainable development strategy. This strategy for Hungary was created this year. It was built up from the different part-strategies such as sustainable sectorial, regional and rural development strategies. This study feeds on the sustainable rural development strategy. It also wants to show how the sustainable development of Hungarian rural areas can connect to the strategic directions of the EU and how it can achieve the elements of sustainable development. But before showing the directions and measures taken, we will introduce the most important social and economic trends of Hungarian rural areas to give light to the starting point of the implementation of sustainable development strategy. 